January 2017

\title{
Banking on Diversity: Does Gender Diversity Improve Financial Firms' Risk Oversight
}

Kristin N. Johnson

Seton Hall University

\section{Recommended Citation}

Kristin N Johnson, Banking on Diversity: Does Gender Diversity Improve Financial Firms' Risk Oversight, 70 SMU L. REV. 327 (2017)

https://scholar.smu.edu/smulr/vol70/iss2/5

This Article is brought to you for free and open access by the Law Journals at SMU Scholar. It has been accepted for inclusion in SMU Law Review by an authorized administrator of SMU Scholar. For more information, please visit http://digitalrepository.smu.edu. 


\title{
Banking on Diversity: Does Gender Diversity IMPROVE FinANCIAL Firms' Risk Oversight?
}

\author{
Kristin N. Johnson*
}

TABLE OF CONTENTS

I. INTRODUCTION ................................ 328

II. SENIOR MANAGEMENT AND BOARDS OF

DIRECTORS ............................. 332

III. WHY BUILD DIVERSE BOARDS? .............. 337

A. Enhanced Financial Performance ............ 338

1. Studies Finding a Positive Relationship Between

Gender Diversity and Firm Performance......... 339

2. Studies Finding a Negative or Inconclusive

Relationship Between Gender Diversity and Firm

Performance ............................. 342

B. Better Governance ........................ 344

1. Misconduct Risk Related Governance Failures .... 345

2. Excessive Risk-Taking Related Governance

Failures ................................... 349

C. Alternative Rationales .................... 352

IV. WOMEN ON CORPORATE BOARDS: A STRATEGY

FOR IMPROVING RISK OVERSIGHT ........... 356

A. EMPirical Evidence on Women and RisK

Management in Financial Institutions ......... 356

B. Evidence Demonstrating Effective Use of Risk

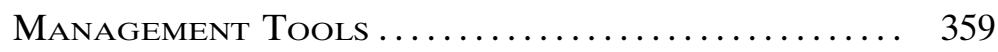

1. Conventional Risk Management Tools ........... 359

2. Governance as a Risk Management Tool ........ 360

3. Culture as a Risk Management Tool ............ 362

V. DIVERSIFYING STRATEGIES TO MITIGATE RISK

EXPOSURE .............................. 363

A. Institutional Investors, Shareholder

Proposals, and Board Diversity Initiatives ..... 364

B. Civil Rights Legislation ..................... 366

* Professor of Law, Seton Hall University Law School; B.S., Edmund A. Walsh School of Foreign Service, Georgetown University with honors; J.D., University of Michigan Law School. For his careful review of earlier drafts, I thank Carlos Lopez. For significant research assistance, I thank my research assistants Yolanda Bromfield, Beata Safari, Sarah Wilbur, and Carla Zavala. 
C. Derivative Litigation: A Risk Management Case STUdy .................................... 373

VI. CONCLUSION ............................... 376

\section{INTRODUCTION}

I N 2007, a financial crisis ensconced global markets. As details of the crisis began to unfold, scholars raised questions regarding the influence of certain structural and organizational dynamics within the financial firms at the center of the crisis. For almost a century, a complex web of federal legislation has aimed to protect taxpayers from the negative consequences of financial institutions' business decisions. ${ }^{1}$ Banking laws, for example, include specific capital and reserve requirements, governance mandates, and detailed licensing standards to reduce systemic risk. ${ }^{2}$ Federal securities laws include an intricate mandatory disclosure framework created to protect investors and to promote efficient and transparent markets. ${ }^{3}$

In the run up to the financial crisis, financial market participants intentionally engaged in regulatory arbitrage, designing financial products that had features removing them from the ambit of regulatory oversight. ${ }^{4}$ After the crisis, risk management scholars posited that the market participants who created and traded these financial products in the shadows of financial markets may have been influenced by an insular culture within financial firms, a culture that encouraged excessive risk-taking. ${ }^{5}$ Adding

1. See infra Part II. A. The term "financial institution" refers to investment banking firms, bank holding companies, and traditional depository banks or thrifts that engage in investment businesses in the financial services industry-including custodial, brokerage, lending, and underwriting services for securities and other assets, insurance companies, hedge funds, private equity funds, and mutual funds. Anthony SAunders \& Marcia Millon Cornett, Financial Institutions Management: A Risk Management ApPROACH 97-103 (6th ed. 2008). The literature also refers to financial institutions as financial intermediaries. Richard S. Carnell et al., The Law of Banking and Financial INSTITUTIONS 36-38 (5th ed. 2013).

2. For a discussion of systemic risk see Kristin N. Johnson \& Steven A. Ramirez, New Guiding Principles: Macroprudential Solutions to Risk Management Oversight and Systemic Risk Concerns, 11 U. St. Thomas L.J. 386, 426 (2014); See Kristin N. Johnson, Macroprudential Regulation: A Sustainable Approach to Regulating Financial Markets, 2013 U. Ill. L. Rev. 881, 897 n. 103 [hereinafter Macroprudential Regulation]; Iman Anabtawi \& Steven Schwarcz, Regulating Systemic Risk: Towards an Analytical Framework, 86 Notre Dame L. Rev. 1349, 1351 (2011); Steven L. Schwarcz, Systemic Risk, 97 Geo. L. J. 193, 204 (2008).

3. $I d$.

4. The primary government inquiry into the causes of the financial crisis found that "stunning instances of governance breakdowns and irresponsibility" within financial firms drove all aspects of the crisis as a key cause. Financial Crisis InQuiry Commission, FinANCIAL CRisis Inquiry COMmission Report xix (2011).

5. See, e.g., Arthur E. Wilmarth, Jr., The Dodd-Frank Act: A Flawed and Inadequate Response to the Too-Big-to-Fail Problem, 89 Or. L. REv. 951, 954 (2011); The Causes and Current State of the Financial Crisis Before the Financial Crisis: Hearing Before the Financial Crisis Inquiry Commission (2010) (Statement of Sheila C. Bair, Chairman, Fed. Deposit Ins. Corp.), http://fcic.law.stanford.edu/documents/view/2144 [https://perma.cc/ 8SWG-GJEC]; Viral V. Acharya \& Matthew Richardson, Causes of the Financial Crisis, 21 
to the precipitating conditions that contributed to the recent financial crisis, the compensation structure in financial institutions ${ }^{6}$ created the impression for many market participants that they would not be held personally accountable for the long-term consequences of excessive risktaking related to these unregulated products. ${ }^{7}$ Theorists examining the catalysts that led to the recent financial crisis offered a number of explanations for the migration toward excessive risk-taking in shadow markets. One underexplored argument posits that homogeneity in the decisionmaking circles of financial institutions may have reinforced cognitive biases and stymied careful analysis of risk exposure and risk management. ${ }^{8}$

Notwithstanding undeniable progress toward greater gender diversity in senior leadership ranks-women increasingly occupy critical leadership positions in politics, the economy, and corporate leadership in the United States and around the world-this Article argues that women remain underrepresented in senior leadership and board positions in the financial services sector. Moreover, this Article contends that the failure to enhance gender diversity in leadership ranks of financial services firms may undermine important goals, such as risk management oversight.

In recent decades, the world has witnessed the appointment and election of women to key senior positions including Angela Merkel's ascendancy to President of the European Council, chair of the G-8 and, in 2005, Chancellor of Germany. ${ }^{9}$ Or consider Christine Lagarde's elevation to the French Minister of Economic Affairs Finance and Employment in

CRitical Rev. 195, 195 (2009) (suggesting that the cause of the financial crisis was, at least in part, due to the behavior of large financial institutions; and explaining that financial institutions "had temporarily placed assets — such as securitized mortgages - in off-balancesheet entities, so that they did not have to hold significant capital buffers against them ... [and that] the capital regulations ... . allowed banks to reduce the amount of capital they held against assets that remained on their balance sheets-if those assets took the form of AAA-rated tranches of securitized mortgages. Thus, by repackaging mortgages into mortgage-backed securities, whether held on or off their balance sheets, banks reduced the amount of capital required against their loans, increasing their ability to make loans manyfold. The principal effect of this regulatory arbitrage, however, was to concentrate the risk of mortgage defaults in the banks and render them insolvent when the housing bubble popped.").

6. Lucian A. Bebchuk \& Holger Spamann, Regulating Bankers' Pay, 98 Geo. L.J. 247, 249 (2010).

7. See, e.g., Kristin N. Johnson, Governing Financial Markets: Regulating Conflicts, 88 Wash. L. Rev. 185, 227 (2013) [hereinafter Governing Financial Markets].

8. See, e.g., Kristin Johnson, Steve Ramirez and Cary Martin Shelby, Diversifying to Mitigate Risk: Can Dodd-Frank Act Section 342 Help Stabilize The Financial Sector, 73 Wash. \& LeE L. Rev. 1795 (2016). The United States Government Accountability Office found that as of 2011 senior managers in the financial sector were 89 percent whites and 71 percent males. United States Government Accountability Office, Trends and Practices in the Financial Services Industry and Agencies after the Recent FinANCIAL CRISIS 11, 16 (2013), http://www.gao.gov/assets/660/653814.pdf [https://perma .cc/VSX8-27YE]. These numbers changed little from the numbers prevailing before the Great Financial Crisis at the senior manager level. Id.

9. George Packer, The Quiet German: The Astonishing Rise of Angela Merkel, The Most Powerful Woman in the World, The New Yorker (Dec. 1, 2014), http://www.newyorker.com/magazine/2014/12/01/quiet-german [https://perma.cc/8YY5-7VER]. 
June of $2007 . .^{10}$ In August of 2016, for the first time in history, one of the two major political parties in the United States selected a woman-Hillary Rodham Clinton-to serve as its candidate for the office of Presidency of the United States. ${ }^{11}$ Women leaders are rising to the most senior positions of power around the world. ${ }^{12}$ In addition to capturing positions as heads of state and chief executive officers (CEO) at Fortune 500 companies, women are commanding more senior roles in industries and sectors throughout the economy. The increased presence of women in leadership is partially the result of more women graduating college, completing graduate school, and rising in the corporate ranks. Notwithstanding their success, this narrative is incomplete. While the relative number of women that have achieved top business and political positions has increased, there appears to be a sticking point. The absolute rise in the number of women in the workforce has not fueled a parallel rise in the absolute number of women occupying critical positions in politics and the economy.

Scholars have long posited that introducing greater diversity among decision-making authorities, such as the board of directors and senior executives, could lead to superior outcomes. ${ }^{13}$ Anecdotally, some

10. See, e.g., Who Is Christine Lagarde? A Short Profile of the Woman Who Wants to Lead the IMF, THE ECONOMIST (May 25, 2011), http://www.economist.com/blogs/newsbook/2011/05/who_christine_lagarde [https://perma.cc/92B9-JKHS].

11. Patrick Healy \& Jonathan Martin, Democrats Make Hillary Clinton a Historic Nominee, N.Y. TIMEs, (July 26, 2016), http://www.nytimes.com/2016/07/27/us/politics/dncspeakers-sanders-clinton.html [https://perma.cc/9GC8-M9Z6].

12. For examples of women's achievement, consider the following elections to head of state positions-Ellen Johnson Sirleaf (24th President of Liberia in 2006), The World's 100 Most Powerful Women, Forbes (2016), http://www.forbes.com/profile/ellen-johnsonsirleaf/ [https://perma.cc/32JD-6UTK]; Cristina Fernandez de Kircher (elected president of Argentina in 2007); Alexei Barrionuevo, Argentina's First Lady Elected President, N.Y. Times (Oct. 30, 2007), http://nyti.ms/2dYxwlp [https://perma.cc/HYZ4-EYDP]; Dilma Rousseff (elected President of Brazil in January 2011), Juan Forero, Rousseff is Brazil's First Female President, WAsh. Post (Nov. 1, 2010), http://www.washingtonpost.com/wpdyn/content/article/2010/10/31/AR2010103104552.html [https://perma.cc/Q69R-Z5X8]; and elections to chief executive officer positions - Meg Whitman (CEO of Hewlett-Packard), Forbes 400, Forbes (2016), http://www.forbes.com/profile/meg-whitman/ [https://perma.cc/ 926W-WVGU]; Ursula Burns (CEO of Xerox Corp), The World's 100 Most Powerful Women, Forbes (2016), http://www.forbes.com/profile/ursula-burns/ [https://perma.cc/Q7HYQ37B]; Marissa Mayer (CEO of Yahoo), The World's 100 Most Powerful Women, Forbes (2016), http://www.forbes.com/profile/marissa-mayer/ [https://perma.cc/B3EX-EW6Y]; Indira Nooyi (CEO of PepsiCo.), The World's 100 Most Powerful Women, Forbes (2016), http://www.forbes.com/profile/indra-nooyi/ [https://perma.cc/GYK4-BUQA]. See CATALYST, WOMEN CEOS OF THE S\&P 500, www.catalyst.org/knowledge/women-ceos-sp-500 [https://perma.cc/S9Q7-NY5Z].

13. David A. Carter et al., Corporate Governance, Board Diversity, and Firm Value, 38 Fin. Review 33, 35 n.3 (2003) (citing Carolyn Brancato \& D. Jeanne Patterson, Board Diversity in U.S. Corporations: Best Practices for Broadening the Profile of Corporate Boards, Research Report No. 1230-99-RR (1999)) (describing the Conference Board report by Brancato and Patterson, but noting that the "report on board diversity in U.S. corporations did not present any statistical tests of the relationship between board diversity and firm value") (citation omitted). See infra Part III.A. It is noteworthy, however, that the results of performance studies demonstrate mixed results regarding the effects of gender diversity on firm performance and any increase in shareholder value. See infra Part III.A. Perhaps even more significantly, correlations are not synonymous with causation; thus, 
commentators suggested that the lack of gender diversity led to an overheating of financial markets and signaled that greater gender diversity would have moderated the irrational exuberance that fueled the housing bubble. ${ }^{14}$ The ego and bravado that inspired blind allegiance to quantitative models and a cowboy culture that celebrated excessive risk-taking clearly contributed to the convergence of risk management failures that led to the recent financial crisis. ${ }^{15}$ The observation regarding gender diversity, however, introduces a set of questions regarding diversity and risk management that merits exploration. When one considers the risk management failures that large and systemically important financial institutions ${ }^{16}$ endured during the financial crisis, these questions become all the more poignant.

For decades, scholars have touted the benefits of broader gender inclusion policies. ${ }^{17}$ Some, however, argue that the case in favor of greater gender diversity requires additional evidence. ${ }^{18}$ This Article draws on interdisciplinary literature to explore the benefits and controversies surrounding gender diversity leadership studies. ${ }^{19}$ Deconstructing the

even where firms with greater gender diversity outperformed firms with less gender diversity, "changes in corporate value (and presumably shareholder value) cannot be statistically attributed solely to the presence or absence of a small number of individuals of any background on a board of directors." Corporate Governance, Board Diversity, and Firm Value, supra note 13 , at 35 . As the discussion will indicate, the "[m]etrics measuring the chain of events are not precise" and one cannot place too much emphasis on the connection or describe the findings as causal. Id.

14. Christine Lagarde, former Minister of Economic Affairs, Finance, and Employment of France and Managing Director of the International Monetary Fund (IMF), eloquently argued, if "Lehman Brothers had been 'Lehman Sisters,' today's economic crisis clearly would look quite different." Christine Lagarde, What if it Had Been Lehman Sisters?, N.Y. Times (May 11, 2016, 6:00 AM), http://dealbook.nytimes.com/2010/05/11/ lagarde-what-if-it-had-been-lehman-sisters/?_r=0 [https://perma.cc/ZWY3-3LWG]. Referencing a study examining a sample of banks around the world that demonstrates that less than twenty percent of bank board members are women and only three percent of bank Chief Executive Officers (CEOs) are women, Lagarde described the need for greater gender diversity on financial institution management teams. Id. Former Citigroup Chief Financial Officer (CFO) Sallie Krawcheck shared similar reflections, positing that in her experience diverse teams are more effective decision-makers due to the greater spectrum of their perspectives. See Sallie Krawcheck, Women's Fund Seeks Share of Prosperity for Female-Focused Firms, PBS Newshour (Aug. 5, 2014, 6:32 PM), http://www.pbs.org/newshour/bb/womens-fund-seeks-share-prosperity-female-focused-firms/ [https://perma.cc/ P333-9VYT].

15. See infra Part III.

16. The businesses described as financial institutions in this Article include investment banking firms, bank holding companies, and traditional savings and commercial deposit banks or thrifts that engage in investment businesses in the financial services industry including custodial, brokerage, lending, and underwriting services for securities and other assets. In addition, these businesses may offer advisory services for complex transactions such as mergers or acquisitions. Because of the services that these businesses provide, commentators also describe financial institutions as financial intermediaries. ANTHONY SAUNDers \& Marcia Millon Cornett, Financial Markets and Institutions 10-17 (5th ed. 2012).

17. See infra Part III.

18. See infra Part III.A. See also David A. Carter, Frank D'Souza, Betty J. Simkins \& W. Gary Simpson, The Gender and Ethnic Diversity of US Boards and Board Committees and Firm Financial Performance, 18 Corp. GovernanCe: An InT'L Rev. 396, 400 (2010).

19. See infra notes 55-105 and accompanying text. 
discussion offers a valuable pathway to mitigate excessive risk-taking within individual financial institutions and across the financial services sector.

This Article surveys empirical studies examining the narrow question of whether the inclusion of greater numbers of women in senior leadership positions and on the boards of directors may reduce excessive risk taking in financial institutions. While there is a significant literature exploring the impact of gender and racial diversity on better corporate governance and improved corporate performance, only a handful of studies have examined the potential influence of senior executive and board gender diversity on risk management in financial services firms.

Employing the results from these studies, this Article surveys studies examining the narrow question of whether including greater numbers of women in senior leadership positions and on boards of directors enhances the performance of financial services firms. Only a handful of studies have examined the impact of senior women and female board members on financial services firms. Based on the conclusions presented by the studies, this Article is among the earliest contributions in the literature to examine whether increasing the representation of women in leadership positions in the financial services industry may enhance risk management in financial markets.

While research examining the impact of diversity on firms' financial performance presents varying results, the early evidence on the impact of diversity on risk management oversight for financial institutions offers significant promise. After surveying the empirical literature exploring gender diversity and risk management, this Article explains that there may be other important reasons to encourage board diversity among financial services firms. A failure to consider the value of gender diversity may involve activist institutional investors' campaigns aimed at increasing diversity on corporate boards and in senior leadership ranks, anti-discrimination litigation and shareholder derivative litigation.

Part II of this Article identifies the senior management roles within large publicly-traded firms and describes the role of the board of directors. Part III surveys the empirical research regarding diversity in leadership and claims that diversity may influence the financial performance of the firm, governance or other decision-making processes and outcome factors. Part IV demonstrates that gender diversity is correlated to better risk management decision-making and outcomes in financial services firms. Part V presents three additional reasons for businesses to thoughtfully consider gender diversity in leadership within financial services firms. This Part considers the threats posed by shareholder campaigns devoted to gender diversity in leadership, anti-discrimination suits and shareholder litigation. Finally, Part VI concludes.

\section{SENIOR MANAGEMENT AND BOARDS OF DIRECTORS}

State law and state courts assign decision-making authority to the 
boards of directors of corporations. ${ }^{20}$ Among other duties boards manage the internal affairs of corporations by monitoring a corporation's performance, assisting in strategic decisions and offering advice to the executive officers of the corporation. ${ }^{21}$ Moreover, state courts and lawmakers accord significant deference to boards of directors regarding the execution of their duties. 22

State statutes direct the owners of the corporation to elect a board of directors and empower the board to make important decisions on behalf of the owners. ${ }^{23}$ Section 141(a) of Delaware General Corporations law recognizes the board of directors as the primary decision-making authority in the corporation and provides that a corporation's "business and affairs ... shall be managed by or under the direction of a board of directors." 24 Similarly, New York General Business Corporations Law indicates that "the business of a corporation shall be managed under the direction of its board of directors." 25 The board may rely on briefings from senior executive officers before making important decisions, but decision-making authority remains with the board. ${ }^{26}$ Consequently, many refer to boards as monitors who are responsible for ensuring the corporation's compliance with state and federal law. ${ }^{27}$

It is possible, however, for the board to delegate responsibility for management of the corporation using one of three approaches. Under Section 141(c) of the Delaware General Corporations Law, the board may: (1)

20. See, e.g., Del. Code Ann. tit. 8, §141(a) (2015).

21. Colin B. Carter \& Jay W. Lorsch, Back to the Drawing Board 67-68 (2004) (discussing three key functions of a board: monitoring performance, making key decisions, and giving advice); Daniel P. Forbes \& Frances J. Milliken, Cognition and Corporate Governance: Understanding Boards of Directors as Strategic Decision-Making Groups, 24 Acad. Mgmt. Rev. 489, 492 (1999) (discussing activities that a board may participate in that increase the effectiveness of both the board and the company).

22. Corporate managers' decisions are protected by the business judgment rule, under which courts will not interfere with directors' decisions absent fraud, illegality, self-dealing, or lack of good faith. See, e.g., Shlensky v. Wrigley, 237 N.E.2d 776, 781 (Ill. App. Ct. 1968) ("Directors are elected for their business capabilities and judgment[,] and the courts cannot require them to forego their judgment because of the decisions of directors of other companies. Courts may not decide these questions in the absence of a clear showing of dereliction of duty on the part of the specific directors ...."); Warshaw v. Calhoun, 221 A.2d 487, 492-93 (Del. 1966) ("In the absence of a showing of bad faith on the part of the directors or of a gross abuse of discretion[,] the business judgment of the directors will not be interfered with by the courts.").

23. See, e.g., Del. Code Ann. tit. 8, §141(a) (2016).

24. See $\$ 141(\mathrm{a})$.

25. See $\$ 141(\mathrm{c})$; N.Y. Bus. Corp. LaW $§ 701$ (McKinney 2016); see also Michael C. Jensen \& William H. Meckling, Theory of the Firm: Managerial Behavior, Agency Costs and Ownership Structure, 3 J. FIn. ECON. 305, 352 (1976).

26. See Del. Code Ann. Tit. 8, §141(e) (2016).

27. See Elizabeth Cosenza, The Holy Grail of Corporate Governance Reform: Independence or Democracy?, 2007 BYU L. REv. 1, 17-18 ("Whereas in the 1960s most boards had a majority of in-house, non-independent directors, most boards today have a majority of outside, independent directors."); Tamar Frankel, Corporate Boards of Directors: Advisors or Supervisors?, 77 U. CIN. L. REv. 501, 504 (2008). 
designate a board committee;28 (2) employ an external expert;29 or (3) appoint senior executives. ${ }^{30}$ First, the board of directors may elect to create board committees consisting of a select group of board members and others with expertise to assist the designated committee. ${ }^{31}$ For example, many corporate boards appoint a compensation committee that recommends the appropriate amount of remuneration for board members and senior executives of the corporation. ${ }^{32}$ Committees generally only have the authority to make recommendations; ${ }^{33}$ the authority to make a final decision typically remains with the board. ${ }^{34}$ Even when committees exercise decision-making authority, the board retains the ability to reject or override any committee decisions. ${ }^{35}$ Similar to board elections for large publicly-traded corporations, board committee appointments are highly competitive. In order to retain a key committee appointments, members may feel pressure to agree with policies and practices championed by the chairman of the board who is often the most senior executive of the corporation - the CEO. ${ }^{36}$

Upon creating a committee to address specific concerns, the board of directors typically outlines the committee's charge in a charter. ${ }^{37}$ Board

28. See Del. Code Ann. Tit. 8, §141(c) (2016); see also Grimes v. Donald, 673 A.2d 1207, 1214-15, 1219 (Del. 1996); In re Walt Disney Co. Derivative Litig., 906 A.2d 27, 54 (Del. Ch. 2006) ("The Delaware General Corporation Law (DGCL) expressly empowers a board of directors to appoint committees and to delegate to them a broad range of responsibilities, which may include setting executive compensation. Nothing in the DGCL mandates that the entire board must make those decisions. At Disney, the responsibility to consider and approve executive compensation was allocated to the compensation committee, as distinguished from the full board. The Chancellor's ruling-that executive compensation was to be fixed by the compensation committee-is legally correct.").

29. See Del. Code Ann. Tit. 8, §141(e) (2016).

30. See In re Walt Disney Co. Derivative Litig., 907 A.2d 693, 697, 745 (Del. Ch. 2005), aff'd, 906 A.2d 27 (Del. 2006).

31. See Smith v. Van Gorkom, 488 A.2d 858, 872 (Del. 1985); Grimes v. Donald, 673 A.2d 1207, 1219 (Del. 1996); In re Walt Disney Co. Derivative Litig., 907 A.2d 693, 707 (Del. Ch. 2005).

32. See, e.g., In re Walt Disney Co., 907 A.2d at 707; see also Margaret M. Blair \& Lynn A. Stout, A Team Production Theory of Corporate Law, 85 VA. L. Rev. 247, 315 (1999); Lisa M. Fairfax, The Uneasy Case for the Inside Director, 96 IowA L. REv. 127, 136-37 (2010); Jill E. Fisch, Taking Boards Seriously, 19 Cardozo L. Rev. 265, 271 (1997) (warning that reforms calling for uniform standards for boards of directors may not improve corporate governance); Ronald J. Gilson \& Reinier Kraakman, Reinventing the Outside Director: An Agenda for Institutional Investors, 43 StAn. L. Rev. 863, 872 (1991); Donald C. Langevoort, The Human Nature of Corporate Boards: Law, Norms, and the Unintended Consequences of Independence and Accountability, 89 GEO. L.J. 797, 805 (2001).

33. Grimes, 673 A.2d at 1214-151207 (Del. 1996).

34. Id. (describing the difference between delegation and abdication).

35. Stephen M. Bainbridge, Why A Board? Group Decisionmaking in Corporate Governance, 55 VAND. L. Rev. 1, 10, 12 (2002) [hereinafter Bainbridge, Why a Board?].

36. See Langevoort, supra note 32, at 805.

37. See, e.g., Risk Policy Committee Charter, JP Morgan Chase \& Co., https://www .jpmorganchase.com/corporate/About-JPMC/ab-risk-committee.htm [https://perma.cc/ D2KK-ZG6G]; Risk Management Committee Charter, Citigroup (2016), http://www.citigroup.com/citi/investor/data/rmfc.pdf [https://perma.cc/T3WW-42TL]; Committee Composition, BANK OF AMERICA, http://investor.bankofamerica.com/phoenix.zhtml?c=71595\& $\mathrm{p}=$ irol-govcommcomp\#fbid=Kih3CTJytcZ [https://perma.cc/33NU-PZNZ] (providing Board Committee charters for download). 
committee charters indicate the specific issues that the board assigns the committee to monitor or manage. ${ }^{38}$ For example, a board committee tasked with risk management oversight advises the board regarding the effectiveness or accuracy of risk controls, risk management policies, or internal audits and internal controls. ${ }^{39}$ The board committee may develop best practices or formal mandatory policies that dictate how executives and employees should address a specific class of issues. ${ }^{40}$

Second, boards of directors often employ experts to advise the board on technical matters that require board approval. ${ }^{41}$ For example, while senior managers may conduct internal audits and prepare financial statements to satisfy regulatory requirements, many corporations also hire independent, external auditors to evaluate the firm's disclosures, confirming the accuracy of internal managers' contributions. ${ }^{42}$ Similarly, in connection with a decision to sell shares of stock to the public, boards of directors often consult with investment banks to develop a process for selling the shares, to assist in creating interest in the public offering, and to estimate the appropriate price or price range for the shares distributed in a public offering. ${ }^{43}$ Likewise, in connection with the sale of a controlling interest in a business or substantially all of the assets of a business, the board may request that an investment bank issue a fairness opinion indicating that the board has correctly estimated the value of the company's assets. ${ }^{44}$

Finally, the board of directors may appoint a senior executive officer, such as the CEO or chief financial officer (CFO), to supervise the day-to-

38. See, e.g., JP Morgan Chase \& Co., supra note 37.

39. See id. " "The purpose of the Board of Directors' Risk Policy Committee ("DRPC") is to assist the Board in its oversight of the operation of the Firm's global risk management framework and to approve and periodically review the primary risk-management policies of the Firm's global operations."); BANK OF AMERICA, ENTERPRISE RISK COMMITTEe CHARTER 1 (2016), http://phx.corporate-ir.net/External.File?item=UGFyZW5 OSUQ9MjY1NjQ4fENoaWxkSUQ9LTF8VHlwZT0z\&t=1??? [https://perma.cc/6TP7$\mathrm{XXM} 2]$ (The committee is "responsible for overseeing the Company's overall risk framework, risk appetite and the Chief Executive Officer's, the Chief Risk Officer's and senior management's identification of, measurement of, monitoring of, and control of key risks.").

40. See, e.g., JP Morgan Chase \& Co., supra note 37 (The committee will "[a]pprove the Firm's Risk Appetite Policy and annually review and approve any material changes to such policy. Approve such policies as may be designated by the DRPC as Primary Risk Policies, and annually review and approve any material changes to such policies.”); BANK of AmericA, ??? supra note 39 (The committee will "[r]eview with senior management the Company's significant policies, procedures, processes and systems, as requested by the Committee or required by regulation, for the identification of, management of, and planning for risks on an enterprise[-]wide basis.").

41. See, e.g., Omnicare, Inc. v. Laborers Dist. Council Constr. Indus. Pension Fund, 135 S.Ct. 1318, 1327-30 (2015); Virginia Bankshares, Inc. v. Sandberg, 501 U.S. 1083, 1088, 1090-91 (1991); Smith v. Van Gorkom, 488 A.2d 858, 875-77 (Del. 1985).

42. See supra notes $37-40$ describing risk management committee charters.

43. See, e.g., Smith, 488 A.2d at 877-78 (finding that the board lacked valuation information adequate to arrive at an informed decision because "[n]one of the directors, Management or outside, were investment bankers or financial analysts. Yet the Board did not consider recessing the meeting ... to give it time to elicit more information as to the sufficiency of the offer" from specialists.).

44. See id. at 876 (suggesting that fairness opinions, though not required as a matter of law, are an adequate way to evaluate a transaction). 
day operations of the corporation. ${ }^{45}$ Hiring these professional managers mitigates the responsibilities of the board for the daily operations of the corporation. At the same time, employing senior executives also creates what scholars refer to as an "agency problem"- that is, the risk that agents may act in their own self-interest, rather than in the best interests of those who hired them. ${ }^{46}$ To mitigate agency costs, state corporate laws require corporations to establish decision-making and internal organizational structures or systems of checks and balances. ${ }^{47}$ Among other things, these laws regulate the powers and duties of individuals who serve as corporate officers or directors. As noted above, the most senior officers, such as the CEO or CFO, typically serve as members of the board of directors. ${ }^{48}$ In the absence of oversight, executives may shirk their duties, lack the requisite skills to execute their duties, or simply steal from the company. To address this danger, the board must monitor the senior executives to ensure that they implement board policies and facilitate the corporation's compliance with applicable laws and regulations. ${ }^{49}$

State law does not outline the qualifications for executives or directors. Typically, corporations seek to appoint officers and directors who inspire confidence and attract investors. Board members generally seek to identify mangers with demonstrated track records, leadership skills, a background or expertise in the field of the corporation's operations, and relevant professional licenses, including licenses to practice law or accounting. ${ }^{50}$

Certain executive positions demand a strong understanding of technical subjects. For example, the CFO is responsible for compiling, processing, and presenting information regarding the financial condition of the corporation, and for advising the corporation regarding investing, selling shares of stock, and incurring debt obligations, among other financial matters. ${ }^{51}$ The CFO's responsibilities demonstrate the significance of this executive's role in a corporation. ${ }^{52}$

Are boards and executives effective at executing the assigned tasks? ${ }^{53}$ Scholars' insightful arguments in the debate regarding shareholder primacy and the emerging literature inquiring whether boards are dysfunc-

45. Nicola Faith Sharpe, Informational Autonomy in the Boardroom, 2013 U. ILL. L. REv 1089, 1114.

46. Jensen, supra note 25 , at 308.

47. Sharpe, supra note 45 , at 1120-21.

48. Geoffrey Miller, The Law of Governance Risk Management and ComPLIANCE 107, 111-12 (2014).

49. In re Caremark Int'l Inc. Derivative Litig., 698 A.2d 959, 970 (Del. Ch. 1996).

50. Miller, supra note 50, at 107.

51. See generally Sharpe, supra note 45, at 1117.

52. See generally Nicola Faith Sharpe, Questioning Authority: The Critical Link Between Board Power and Process, 38 J. Corp. L. 1, 3 (2012).

53. See Jonathan R. Macey, Corporate Governance: Promises Kept, Promises BROKEN 56 (2008) ("A crucial, but wholly unexamined, assumption underlying this foundational theory of corporate governance is that boards of directors can reasonably be expected to do what is required of them. This assumption cannot withstand scrutiny."). 
tional and inept leave a number of questions unresolved. ${ }^{54}$ Conventional wisdom suggests that using boards as an organizational framework may yield many benefits; however, scholars caution that it is worth exploring our allegiance to the monitoring board as well as assumptions regarding the cognitive and group decision-making limitations exacerbated by this framework.

\section{WHY BUILD DIVERSE BOARDS?}

Examining the formal structure of management and the board creates the impression that decision-making processes within corporations are deeply imbued with expertise and benefit from well-developed mechanics and long-standing traditions. Corporate leadership has also, however, been accurately described as self-interested, greedy, and plagued by conflicts of interest. ${ }^{55}$ To address weaknesses in board decision-making and improve decision-making outcomes, some commentators have posited that corporations should focus on bringing greater diversity to senior leadership and the boardroom.

Over the last few decades, questions regarding the benefits of board diversity have intensified in the United States and around the world. A common argument regarding the benefits of diversity emphasizes two shareholder welfare-centered benefits of board diversity: enhanced corporate financial performance and better governance. These two benefits often anchor the business case for diversity. ${ }^{56}$ In fact, many advocates of board diversity posit that shareholder wealth maximization and enhanced leadership diversity are complimentary goals. ${ }^{57}$

This Part explores the merits of these elements of the business case for diversity. After examining these reasons offered in support of greater board diversity, this Part criticizes the use of such a narrow lens. This Part concludes by arguing that more informed arguments supporting board diversity acknowledge the broader constituencies that influence corporate

54. See, e.g., Stephen M. Bainbridge, Director Primacy and Shareholder Disempowerment, 119 Harv. L. Rev. 1735, 1747 (2006) (supporting board authority and arguing for boards to exercise significant discretion); Stephen M. Bainbridge, Director Primacy: The Means and Ends of Corporate Governance, 97 N. U. L. REv. 547, 547 (2003); Bainbridge, supra note 35, at 12-41 (explaining that group decisions are superior to individual decisionmaking processes). Others question deference to the board of directors. See, e.g., Lucian Arye Bebchuk, The Case for Increasing Shareholder Power, 118 HARv. L. REv. 833, 894 (2005); MACEY, supra note 53, at 56; Gilson, supra note 32, at 872.

55. See Alces, supra note 27 , at 789.

56. Corporate Governance, Board Diversity, and Firm Value, supra note 13, at 35.

57. Interviewed by the Wall Street Journal in an article exploring the rationale for board diversity, Herman Bulls, an African-American and CEO of the real-estate advisory group Comfort Systems USA Inc.- a commercial heating and ventilation company-explained that he sees his fiduciary responsibility to the shareholders of the company; his motivations to enhance diversity are not motivated by social engineering. Phred Dvorak, Some Things Don't Change. Sarbanes-Oxley Was Expected to Increase the Number of Minority Directors. What Happened?, WALL ST. J., (Jan. 14, 2008), http://www.wsj.com/articles/SB119998932208381439 [https://perma.cc/6T9J-PXKR] (with Bulls indicating that he "can talk about diversity. But there ought to be a business case."). 
decisions, as well as the signaling effect of board nomination and election processes.

\section{A. Enhanced Financial Performance}

For many corporate executives, board members, scholars, and jurists, discussions regarding structural corporate governance reform begin with careful consideration of whether a proposed reform enhances shareholder value ${ }^{58}$ Consequently, the business case for diversity suggests that diversity improves a firm's financial performance and governance. ${ }^{59}$ While theoretical arguments drawn from resource dependence theory, human capital theory, agency theory, and social psychology offer some guidance, this Part examines the empirical evidence exploring the impact of gender diversity on a firm's financial performance. ${ }^{60}$

A number of studies investigate the relationship between diversifying corporate boards and the financial performance of the firm. ${ }^{61}$ Studies completed in the 1980s and 1990s offered evidence supporting, in some instances, and rejecting, in other instances, the notion that greater gender diversity enhances boards' decision-making processes. ${ }^{62}$ Typically, theo-

58. Corporate Governance, Board Diversity, and Firm Value, supra note 13, at 34.

59. See Marcus Alm \& Jonathan Winberg, How Does Gender Diversity on Corporate Boards Affect the Firm Financial Performance, (Aug 1, 2016) (Unpublished B.A. thesis, University of Gothenburg); Nuria Reguera-Alvarado, Pilar de Fuentes \& Joaquina Laffarga, Does Board Gender Diversity Influence Financial Performance? Evidence from Spain, J. Bus. Eтhics 2, 5 (2015); Caspar Rose, Does Female Board Representation Influence Firm Performance? The Danish Evidence, 15 Corp. Governance: An Int'l Rev. 404, 406 (2007).

60. See, e.g., Benjamin E. Hermalin \& Michael S. Weisbach, The Effects of Board Composition and Direct Incentives on Firm Performance, 20 Fin. Mgmt. 101, 111 (1991) (surveying the literature regarding the business case for corporate board diversity). Scholars and theorists have advanced many reasons for diversifying corporate boards including arguments that general workplace diversity inspires conversations regarding board diversity. Corporate Governance, Board Diversity, and Firm Value, supra note 13, at 36 ("Because demographic projections indicate the marketplace is becoming more diverse, matching the diversity of a company to the diversity of the company's potential customers and suppliers increases the ability to penetrate markets."). Second, others argue that diversity increases creativity and innovation. Id. ("attitudes, cognitive functioning, and beliefs are not randomly distributed in the population, but tend to vary systematically with demographic variables such as age, race, and gender.") Third, "diversity produces more effective problem-solving. While heterogeneity may initially produce more conflict in the decision making process, the variety of perspectives that emerges cause decision makers to evaluate more alternatives and more carefully explore the consequences of these alternatives." Id. Finally, according to the literature, "diversity enhances the effectiveness of corporate leadership. Homogeneity at the top of a company is believed to result in a narrow perspective while diverse top managers take a broader view." Id.

61. See, e.g., Mijntje Lückerath-Rovers, Women on Boards and Firm Performance, 17 J. Mgmt. \& Gov't 491, 491 (2013).

62. See supra notes 55-105 and accompanying text. See also Policy and Impact Comm. of the Comm. For Econ. Dev., Fulfilling the Promise: How Many More Women on Corporate Boards Would Make America and American Companies More Competitive 11, 13-14 (2012), http://www.fwa.org/pdf/CED_WomenAdvancementonCorporateBoards .pdf [http://perma.cc/A57Y-8JWA] (concluding that women directors help deliver "measurable economic gains" and that American businesses have failed to capitalize on the competitive advantage that diversity offers); Anthony F. Jurkus et al., Women in Top Management and Agency Costs 11 (Working Paper Mar. 2011), https://papers.ssrn.com/ 
rists' analysis evaluating the effect of gender diversity involves inquiring as to whether a statistically significant number of firms in a sample of large corporations experienced positive or negative results after an increase in the number of women board members. ${ }^{63}$ Theorists measure the impact of gender diversity by employing an accounting metric such as the relative measure of return on equity (ROE), return on invested capital (ROIC), or return on sales (ROS). ${ }^{64}$ The following subsections explore the empirical evidence supporting, rejecting or identifying the limits of measuring the results of increased gender diversity on boards using financial performance metrics.

\section{Studies Finding a Positive Relationship Between Gender Diversity and Firm Performance}

In 2007 and 2011, a research center, Catalyst, published two of the most cited recent studies on gender diversity and board performance. ${ }^{65}$ The 2007 Catalyst study - a univariate analysis compared the means of two groups over a four-year period (2001-2004) and analyzed ROE, ROS, and ROIC of the sample group of Fortune 500 companies. ${ }^{66}$ Due to the lack of control variables, the study does not explain a correlation and this kind of means comparison may be skewed by any extreme values. ${ }^{67}$ The 2007 Catalyst study ranked the companies based on ROE, ROS and ROIC and considered whether the identified firms had significant gender diversity on the board. The 2007 Catalyst study found that companies in the highest quartile (companies with the highest average percentage of women board directors) outperformed companies in the lowest quartile (companies with the lowest average percentage of women board directors) by $53 \%$ in ROE, $42 \%$ in ROS, and $66 \%$ in ROIC. ${ }^{68}$ Similarly, relying on evidence of the returns of Fortune 500 companies during the 2004-2008 period, the 2011 Catalyst study ranked the companies by their average

sol3/papers.cfm?abstract_id=1085109 [http://perma.cc/PV38-UM6W] (finding a positive relationship).

63. See supra notes 55-105 and accompanying text.

64. See, e.g., Charles B. Shrader et al., Women in Top Management and Firm Performance: An Explanatory Study, 9 J. MANAGERIAL Issues 355, 361, 365 (1997) (analyzing the relationship between the percentage of female board members using accounting measures of financial value such as ROA or ROE); Shaker A. Zahra \& Wilbur W. Stanton, The Implications of Board of Directors' Composition for Corporate Strategy and Performance, 5 INT'L J. MgmT. 229 (1988) (measuring the impact of racial diversity in their canonical analysis that relies on several accounting measures of financial value (e.g., ROE and EPS)).

65. See Lois Joy et al., The Bottom Line: Corporate Performance and Women's Representation on Boards, CATALYST, http://www.catalyst.org/system/files/The_Bottom_Line_ Corporate_Performance_and_Womens_Representation_on_Boards.pdf [htttp://perma.cc/ ZP5N-PA3E]; Nancy M. Carter \& Harvey M. Wagner, The Bottom Line: Corporate Performance and Women's Representation on Boards (2004-2008), CATALYst, http://www.catalyst.org/system/files/the_bottom_line_corporate_performance_and_women $\% 27$ s_repre sentation_on_boards_\%282004-2008\%29.pdf.

66. Lois Joy et al., supra note 65.

67. "These studies have examined historical data and revealed statistically significant correlations. The studies do not, however, establish or imply causal connections." Carter \& Wagner, supra note 65, at 2 .

68. Id. 
percentage of women board directors over the relevant period. The 2011 Catalyst study did not expressly support the findings of the 2007 Catalyst study. The 2011 Catalyst study did, however, find that those in the companies in the highest quartile outperformed the companies in the lowest quartile by $16 \%$ in ROS and $26 \%$ in ROIC. 69

The Credit Suisse Research Institute, established in $2008,{ }^{70}$ similarly examined the relationship between gender diversity and financial performance in a sample of 2,360 companies located in countries around the world and concluded that companies with at least one woman on the board would have outperformed their competitors in terms of share price performance, after controlling for biases from the skew in female representation in certain industries and regions. ${ }^{71}$ The study found that companies with at least one woman director had higher net income growth during a six-year period than companies with no woman directors $(14 \%$ versus $10 \%$, respectively) and that the average ROE of companies with at least one woman on the board over the past six years is $16 \%$, which was 4 percentage points higher than the average ROE of companies with no female board representation (12\%). ${ }^{72}$ The study-also a means comparison- concluded that relative share price outperformance of companies with women on the board "looks unlikely to be entirely consistent, but the evidence suggests that more balance on the board brings less volatility and more balance through the cycle." 73

Other studies using regression analysis have also found a positive relationship between board diversity and performance. In a study of 1,066 publicly traded companies, Renee Adams and Daniel Ferreira (the Adams and Ferreira study) found a significant positive relationship between gender and firm performance as measured by Tobin's Q. ${ }^{74}$ The Adams and Ferreira study, however, found no relationship or a negative relationship between gender diversity and return on assets (ROA). ${ }^{75}$ Examining gender and racial diversity, the Carter, Simkins, and Simpson study pub-

69. Carter \& Wagner, supra note 65 , at 1 . The study found that there was "no significant difference in ROE between companies with the most [women board directors] and those with the least [women board directors]." Id.

70. CRedit Suisse Research Institute, https://www.credit-suisse.com/us/en/investment-banking/indices-research-analytics/research-institute.html [https://perma.cc/43WLKBRZ] (The research institute was founded "to explore new emerging or influential topics. Working with some of the world's most distinguished experts, academics, institutions and Credit Suisse's global network of 400 analysts, the Institute makes this information available throughout the bank for the business units to create innovative products, solutions and services for Credit Suisse's clients.").

71. Mary Curtis et al., Gender Diversity and Corporate Performance, CREDIT SuISSE 12 (2012), https://www.credit-suisse.com/us/en/investment-banking/indices-research-analytics/ research-institute.html [https://perma.cc/GM3P-6MPW].

72. Id. at 14 .

73. Id. at 6 .

74. Renee B. Adams \& Daniel Ferreira, Diversity and Incentives in Teams: Evidence from Corporate Boards (July 21, 2002) (unpublished manuscript) (on file with author). Tobin's Q is a ratio of market value of a firm divided by the replacement cost of its assets. James Tobin, A General Equilibrium Approach To Monetary Theory, 1 J. Money, CrediT AND BANking 15, 21, 29 (1969).

75. Renee B. Adams \& Daniel Ferreira, supra note 74. 
lished in 2003 (Carter, Simkins, and Simpson 2003 study) concluded that there is a significant relationship between greater gender and racial diversity and firm performance as measured by ROA and ROE. ${ }^{76}$ The Carter, Simkins, and Simpson 2003 study "examine[d] the relationships among corporate governance, board diversity, and firm value" for Fortune 1000 firms. ${ }^{77}$ "After controlling for size, industry, and other corporate governance measures," the Carter, Simkins, and Simpson study found that there are "statistically significant positive relationships between the presence of women or minorities on the board and firm value, as measured by Tobin's Q."78

A second study by Carter, D'Souza, Simkins, and Simpson in 2010 (Carter, D'Souza, Simkins, and Simpson 2010 study) examined the relationship between the financial performance of major U.S. corporations whose securities captured in the S\&P 500 index and the participation of women on the boards. According to the Carter, D'Souza, Simkins, and Simpson 2010 study ${ }^{79}$ greater gender and ethnic diversity on important board committees had a positive effect on financial performance as measured by ROA; the study did not find a positive effect on Tobin's Q. A study by Niclas L. Erhardt, James D. Werbel, and Charles B. Shrader concluded that firms in their five-year study of 112 large companies experienced positive performance results as measured by ROA and ROI with increased board gender diversity. ${ }^{80}$ Examining a broader set of questions, including whether women in top management positions positively influence financial performance, the 1997 study of Schrader, Blackburn, and Iles (Schrader study) concluded that "large firms with high percentages of women managers also have high ROS, ROA, ROI and ROE." 81

A study by Vivian Hunt, Dennis Layton, and Sara Prince examining gender and racial diversity and firm performance (Hunt, Layton and Prince study) found a statistically significant relationship between more diverse leadership and better financial performance as measured by earn51.

76. Corporate Governance, Board Diversity, and Firm Value, supra note 13, at 36, 50-

77. Id. at 51. The study defined board diversity "as the percentage of women or minorities (i.e., African-Americans, Asians, and Hispanics) on the board of directors." Id.

78. Id. at 36.

79. The Gender and Ethnic Diversity of US Boards and Board Committees and Firm Financial Performance, supra note 18, at 403. The study involved a least squares regression with firm and time fixed effects and three-stage least squares with firm and time fixed effects during the period 1998-2002.

80. Niclas L. Erhardt, James D. Werbel \& Charles B. Shrader, Board of Director Diversity and Firm Financial Performance, 11 Corp. Governance: An InT'L Rev. 102-111 (2003) ("This study examines the relationship between demographic diversity on boards of directors with firm financial performance. This relationship is examined using 1993 and 1998 financial performance data (return on asset and investment) and the percentage of women and minorities on boards of directors for 127 large US companies. [Eds: Although only 112 companies were able to be used in the study] Correlation and regression analyses indicate board diversity is positively associated with these financial indicators of firm performance. Implications for both strategic human resource management and future research are discussed.") Return on investment measures net income divided by investment capital. Id.

81. Shrader et al., supra note 64 , at 365 . 
ings before interest and taxes (EBIT). The Hunt, Layton, and Prince study found that "[c]ompanies with 10 percent higher gender and ethnic/ racial diversity on management teams and boards in the US ... had EBIT that was 1.1 percent higher; in the UK, companies with the same diversity level had EBIT that was 5.8 percent higher." 82 According to the Hunt, Layton and Prince study, "companies in the top quartile of gender diversity were 15 percent more likely to have financial returns that were above their national industry median." 83 The Hunt, Layton, and Prince study report further concluded that "[c]ompanies in the bottom quartile for both gender and ethnicity/race were statistically less likely to achieve above-average financial returns than the average companies in the dataset (that is, they were not just not leading, they were lagging)." 84 In Demographic Diversity in the Boardroom: Mediators of the Board Diversity-Firm Performance Relationship, Toyah Miller \& María del Carmen Triana examined 326 companies Fortune 500 companies between 2002 and 2005 and found that firms with greater gender and racial diversity had stronger reputations and demonstrated greater innovation than companies with non-diverse boards. ${ }^{85}$

\section{Studies Finding a Negative or Inconclusive Relationship Between Gender Diversity and Firm Performance}

While some studies have identified gender diversity on the board and in executive leadership enhances firm performance, other studies examining the question of gender diversity's impact on firm performance have concluded that there is a negative relationship between firm performance and gender diversity. ${ }^{86}$ In a strong critique of the thesis that board diversity improves performance, Shaker A. Zahra and Wilbur W. Stanton examine a random sample of one hundred Fortune 500 corporations and conclude that the greater the number of diverse board members (women and racial minorities) on the board, the lower the profitability and efficiency of the firm. ${ }^{87}$ According to Zahra and Stanton's study, there is no

82. Vivian Hunt et al., Diversity Matters, McKinsey \& Company (Feb. 2, 2015), http:// www.diversitas.co.nz/Portals/25/Docs/Diversity\%20Matters.pdf [https://perma.cc/3NSFFXSH].

83. Id.

84. Id. (noting that "[t]he results varied by country and industry").

85. Toyah Miller \& María del Carmen Triana, Demographic Diversity in the Boardroom: Mediators of the Board Diversity-Firm Performance Relationship, 46 J. MgmT. STUD. 755, 765-78 (2009).

86. Alm \& Winberg, supra note 59 ("Carter et al. (2010) states that gender diversity on corporate boards result in diverse opinions and critical thinking that makes decisionmaking more time-consuming and less effective ... even though women might have unique skillsets and offer different perspectives that argue financially beneficial, it is not widely accepted in the specialized academic literature that the impact gender diversity has on financial performance has to be positive."). Prior studies associate gender diversity with negative financial result. See, e.g., Øyvind Børen \& Øystein R. Strøm, Governance and Politics: Regulating Independence and Diversity in the Board Room, 37 J. Bus. Fin. \& Асст. 1281 (2010).

87. Zahra \& Stanton, supra note 64 , at $231-33$. The study is a random sample of 100 Fortune 500 companies. 
relationship between diversity and ROE, profit margin, sales to equity, earnings per share or dividends per share. ${ }^{88}$ Other studies found mixed results. The Shrader study referenced in the previous section found positive indicators regarding firm performance, but did not conclude "that higher percentages of women managers on the top management team or on the board of directors were disproportionately associated with higher financial performance." 89

Many perceive the mixed results of the research on financial performance to signal that the impact of gender diversity on firm performance is likely inconclusive. ${ }^{90}$ According to one study, "[h]uman capital theory predicts that the performance of [a corporate] board will be affected by board diversity as a result of diverse and unique human capital but the effect could be either positive or negative" 91 The Carter, Simkins, and Simpson study described earlier ultimately reflects similar uncertainty. While there is evidence of a positive relationship between greater gender diversity with respect to some accounting performance metrics, the study concluded greater gender and ethnic diversity on important board committees had no effect on performance as measured by Tobin's Q. ${ }^{92}$ The Miller and Triana study described above similarly found a positive relationship between gender diversity and certain performance metrics, but not ROI or ROS. 93

Finally, notwithstanding the evidence suggesting a positive relationship between firm financial performance and gender diversity, the data does not support the conclusion that this is a causal relationship between gender diversity and firm performance. ${ }^{94}$ The data may, however, suggest

88. Id. at $232-35$

89. Id.

90. See Alm \& Winberg, supra note 59, at 8 (citing Renée B. Adams \& Daniel Ferreira, Women in the Boardroom and Their Impact on Governance and Performance, $94 \mathrm{~J}$. FIN. ECON. 291, 291 (2009)). "The existing empirical evidence on the relationship between board diversity and firm financial performance is inconclusive in the sense that very different results have been found. Results have shown both positive, negative or no effect of diversity on financial performance. Moreover, previous research has also shown that the diversity of the board has other implications than its impact on financial performance, such as board director behavior and risk taking." From the results of the Adams \& Ferriera study, one may conclude that the "positive impact on companies operating under difficult circumstances with a larger risk of failure." Id.

91. The Gender and Ethnic Diversity of US Boards and Board Committees and Firm Financial Performance, supra note 18, at 399-400 (using regression analysis on a sample of S\&P 500 firms for the period 1998-2002 to measure the effect of women board representation).

92. Id. at 407 .

93. Miller \& Triana, supra note 85 , at $744-75$.

94. See Adams \& Ferreira, supra note 90, at 292. As the results of one study explain, "[t]he evidence on the relation between gender diversity on boards and firm performance is more difficult to interpret. Although the correlation between gender diversity and either firm value or operating performance appears to be positive at first inspection, this correlation disappears once we apply reasonable procedures to tackle omitted variables and reverse causality problems." Id. According to this study, "on average, firms perform worse the greater is the gender diversity of the board." Id. "This result is consistent with the argument that too much board monitoring can decrease shareholder value." Id. 
that upon becoming more profitable, firms begin to adopt more aggressive policies for diversifying corporate boards.

The diversity of methodological approaches, financial performance metrics, sample sizes, and governance structures may offer an alternative explanation for the mixed results. Inherent shortcomings in each of the methodological approaches also adds to the challenges associated with the use of these studies. In other instances, these kinds of uncertainties have plagued efforts to establish direct relationships between corporate governance reforms and successful financial performance or good corporate governance. ${ }^{95}$

\section{B. Better Governance}

Even if the empirical data does not establish that board diversity initiatives directly influence shareholder value, some argue that gender diversity enhances governance and leads to better decision-making process and outcomes. One explanation for better governance processes and outcomes may be that men and women lead differently. ${ }^{96}$ Commentators have argued that women tend to lead in a more collaborative manner that is positively associated with board activity and likely to decrease conflict. ${ }^{97}$ According to a study by Nielsen and Huse, increasing the representation of women directors on the board increases the higher the likelihood of benefits such as increased board engagement and decreased conflict. ${ }^{98}$

Professor Lisa M. Fairfax explores social science research evaluating the contributions of women directors. According to Professor Fairfax "homogenous groups tend toward excessive conformity that undercuts their ability to assess other group members." 99 Applying this conclusion to corporate boards, scholars similarly conclude that heterogeneous

95. Lucian Bebchuk et al., What Matters in Corporate Governance?, 22 REv. FIN. STUD. 783, 823 (2009) (examining twenty-four corporate governance provisions considered significant and finding that eighteen of the factors, including director indemnification, director liability, and director duties, were uncorrelated with firm valuation or abnormal returns); Sanjai Bhagat \& Bernard Black, The Uncertain Relationship Between Board Composition and Firm Performance, 54 Bus. Law. 921, 921 (1999) (finding that firms with majority-independent boards do not perform better than firms with insider directors; while supermajority-independent boards may lead to worse performance); David Finegold, George S. Benson \& David Hecht, Corporate Boards and Company Performance: Review of Research in Light of Recent Reforms, 15 Corp. Governance: An InT'L Rev. 865, 871-72 (2007) (finding mixed and inconclusive results in a meta-analysis of over 100 studies of CEO roles, board independence, board size, and board ownership).

96. See Linda L. Carli \& Alice H. Eagly, Overcoming Resistance to Women Leaders: The Importance of Leadership Styles, in Women AND Leadership: The STATE OF Play And Strategies for Change 127, 127-129 (Barbara Kellerman \& Deborah L. Rhode eds., 2007).

97. See Sabina Nielsen \& Morten Huse, The Contribution of Women on Boards of Directors: Going Beyond the Surface, 18 Corp. Governance: An InT'L Rev. 136, 137, 140 (2010).

98. See id.

99. Lisa M. Fairfax, Clogs in the Pipeline: The Mixed Data on Women Directors and Continued Barriers to Their Advancement, 65 MD. L. REv. 579, 590 (2006). 
groups introduce "a wider range of options and solutions to corporate issues."100

Similarly, Professor Joan Heminway has applied crowd theory to questions regarding the benefits of gender diversity on corporate boards. ${ }^{101}$ Heminway explores the epistemology of the word "crowds,"102 and explains how understanding boards as "crowds" yields valuable guidance for improving board outcomes. ${ }^{103}$ Employing James Surowiecki's framework centered on diversity, independence, and decentralization, Heminway explains how increasing the number of women on boards may introduce "game-changing perspectives and proficiencies." 104 According to Heminway, women enhance board independence "because they are inquisitive and have the capacity to identify different potential options." 105

These investigations, however, beg the question of whether there are ways to structure the board that increase effective group decision-making and enhance risk management. Before turning to examine the impact of gender diversity on risk management and decision-making processes, it may be useful to consider examples of the kinds of governance failures that have prompted previous interventions in the structure of corporate governance.

\section{Misconduct Risk Related Governance Failures}

Many factors may influence boards' decision-making processes. By all accounts, corporate governance-policies and practices that the board employs to make decisions-is most certainly a province of state law. ${ }^{106}$ States have long endeavored to adopt laws that balance the authority assigned to corporate directors with appropriate measures of accountability. ${ }^{107}$ Following several recent corporate governance scandals, Congress has intervened and imposed federal legislation regulating the relationship between shareholders who are the owners of corporations and the professional executives and directors who oversee operations of these businesses.

In 1999, a series of accounting and financial fraud scandals shocked

100. Id.; see also Deborah L. Rhode \& Amanda K. Packel, Diversity on Corporate Boards: How Much Difference Does Difference Make?, 39 Del. J. CoRp. L. 377 (2014).

101. Joan M. Heminway, Women in the Crowd of Corporate Directors: Following, Walking Alone, and Meaningfully Contributing, 21 WM. \& MARY J. WoMEN \& L. 59 (2014).

102. Id. at 62 (explaining that the term crowds encompasses "any group of people who have the ability to act collectively to make decisions and solve problems.") (citation omitted).

103. Id.

104. Id. at 79 .

105. Id. at 82; see also Jayne Barnard, More Women on Corporate Boards? Not So Fast, 13 WM. \& MARY J. WoMen \& L. 703, 711 (2007).

106. See, e.g., Del. Code AnN. tit. 8, §141(a) (2015).

107. See, e.g., Shlensky v. Wrigley, 237 N.E.2d 776, 779 (Ill. App. Ct. 1968). 
investors, regulators, and market participants. ${ }^{108}$ In the decade leading to its salacious bankruptcy in 2001, Enron seized the spotlight and became a corporate phenomenon. ${ }^{109}$ Created in 1985, Enron Corporation-a Texas-based energy resources, commodities, and related services firmgrew rapidly and quickly garnered the respect of investors, peers, and the energy industry. ${ }^{110}$ In the weeks and days before Enron's collapse in the fall of 2001, financial market analysts celebrated Enron as the seventhlargest company in the world. ${ }^{111}$ At the height of its rise in 2000, Enron was valued at nearly $\$ 70$ billion; Enron's shares traded at about $\$ 90$ per share. ${ }^{112}$

At the time of the announcement that Enron had manipulated its financial disclosures, concealed debts, inflated the value of its assets, and relied on hypothetical revenues in its accounting practices, the company's stock price precipitously declined. ${ }^{113}$ By November 30, 2001, Enron's shares traded at less than $\$ 1.00$ per share. ${ }^{114}$ The revelation of Enron executives' misconduct led Enron to file for Chapter 11 bankruptcy protection. ${ }^{115}$

Enron's executives engaged in an extensive fraudulent scheme to inflate the company's earnings and increase its stock price. ${ }^{116}$ Enron used unconventional accounting practices to hide extensive losses through a complex network of partnerships, "special purpose entities" (SPEs). ${ }^{117}$ Enron also transferred the extensive trading losses and debts to investment banking firms using the SPEs. ${ }^{118}$ Enron's external auditor, Arthur

108. See Robert Prentice, Enron: A Brief Behavioral Autopsy, 40 Aм. Bus. L.J. 417, 440 (2003).

109. See id.

110. Richard M. Weber, Jr., Subtle Hazards, 124 BAnking L.J. 324, 335 (2007); See generally, The Enron Collapse: Implications to Investors and the Capital Markets: Joint Hearing Before the Subcomm. on Capital Markets, Ins., and Gov't Sponsored Enters. and the Subcomm. on Oversight and Investigations of the H. Comm. on Fin. Servs., 107th Cong. 62 (2002).

111. The Fortune 500 Largest U.S. Corporations, ForTune (2001), http://archive.for tune.com/magazines/fortune/fortune500_archive/full/2001/ [https://perma.cc/DN2V-RX $3 \mathrm{C}]$.

112. The Fall of Enron, National Public Radio (Jan. 22, 2002), http://www.npr.org/ news/specials/enron/ [https://perma.cc/MBM8-5XHU]; See also The Enron Collapse, supra note 111, at 62. (statement of Rep. Sheila Jackson-Lee) (stating Enron's share price more than quadrupled in value from $\$ 20$ in 1998 to $\$ 90$ in the first half of 2001).

113. See The Enron Collapse, supra note 111, at 28.

114. Id.

115. See Enron: The Real Scandal, The Economist (Jan.17, 2002), http://www.economist.com/node/940091 [https://perma.cc/25HC-P93W].

116. Tracy Coenen, Enron: The Good, the Bad and the Ugly, Wisconsin Law Journal, (June 7, 2006), http://wislawjournal.com/2006/06/07/enron-the-good-the-bad-and-the-ugly/ [https://perma.cc/RT2B-2JQ2].

117. Weber, supra note 110 , at 335.

118. National Public Radio, supra note 112. See also Bill Keller, Enron for Dummies, N.Y. Times (Jan. 26, 2002), http://www.nytimes.com/2002/01/26/opinion/enron-fordummies.html?pagewanted=all [https://perma.cc/3SHN-JYGR] ("To keep its mystique alive and its stock price growing, it set up partnerships where it could bury its losses, or generate imaginary revenues. Here's one of the more audacious examples, pieced together by The Wall Street Journal: Enron invested a bunch of money in a joint venture with Blockbuster to rent out movies online. The deal flopped eight months later. But in the 
Anderson, destroyed documents that indicated that the accounting firm had been facilitating Enron's fraud. ${ }^{119}$ Arthur Anderson later admitted to having made "errors of judgment" when accounting for the debt of Enron's SPEs and off-balance-sheet transactions; Arthur Anderson further acknowledged its role in Enron having overstated profits by nearly $\$ 600$ million from 1997-2000. ${ }^{120}$ Arthur Andersen failed to reveal information regarding Enron's activities and facilitated "one of the biggest frauds in corporate history." 121 Arthur Anderson was likely complicit in advancing Enron's fraud to boost its profits as Anderson expanded into a global conglomerate. ${ }^{122}$

Misconduct risk is a well-known and anticipatable concern for most businesses. ${ }^{123}$ For securities and commodities trading businesses and other firms that facilitate financial market transactions, developing internal controls may mitigate the risk that insiders will attempt to manipulate performance outcomes. Even when there is no evidence of intentional fraud, however, financial market participants may be overly-optimistic; their decisions may reflect over-confidence, and invite market participants to engage in excessively risky activities. ${ }^{124}$

According to one source, the ethos at Enron encouraged values consistent with those at most trading firms-"risk-taking, deal-making, and

meantime Enron had secretly set up a partnership with a Canadian bank. The bank essentially lent Enron \$115 million in exchange for Enron's profits from the movie venture over its first 10 years. The Blockbuster deal never made a penny, but Enron counted the Canadian loan as a nice, fat profit."); see also Weber, supra note 110, at 335-36.

119. Enron: The Real Scandal, supra note 115.

120. Enron: The Real Scandal, supra note 115.

121. National Public Radio, supra note 112. See also Nancy R. Mansfield et al., The Shocking Impact of Corporate Scandal on Directors' and Officers' Liability, 20 U. MIAMI Bus. L. REv. 211, 230 (2012) (stating commentators have referred to the Enron scandal as the "granddaddy of all corporate fraud cases.").

122. Ken Brown \& Ianthe J. Dugan, Arthur Andersen's Fall From Grace Is a Sad Tale of Greed and Miscues, WALl ST. J., (June 7, 2002, 12:01AM), http://www.wsj.com/articles/ SB1023409436545200 [https://perma.cc/GXP2-KGQT].

123. For a careful exploration of "misconduct risk," see Christina Parajon Skinner, explaining that:

Financial misconduct has received markedly different treatment. Although the world's major economies now agree that bank misconduct is a serious problem, they have yet to diagnose it as a market-wide risk that requires forward-looking, preventative, and well-coordinated solutions. Indeed, each jurisdiction still responds to misconduct with primarily an ex post enforcement approach. But misconduct is not only an isolated or idiosyncratic risk that can be spot treated with enforcement. When bankers and traders in large financial institutions manipulate or distort key information, that misconduct can pose broad macro risks. In some instances, such misconduct contributes to asset bubbles by fueling irrational demand; in others, it weakens large institutions by frustrating market discipline and regulatory supervision. At a minimum, misconduct can give rise to a range of social and economic costs by, for example, depressing market confidence or disrupting liquidity. On that view, much like the balance sheet risks that receive so much attention, financial misconduct is also a safety and soundness issue that bank regulators worldwide should seek to address.

Christina P. Skinner, Misconduct Risk, 84 Fordham L. Rev. 1559, 1561-62 (2016) (internal citations omitted).

124. Prentice, supra note 108, at 430. 
thinking outside the box." 125 The controls that served to ensure accountability, however, "appeared loose at best."126 Management adopted a hands-off approach rather than monitor and address abuses of internal controls. ${ }^{127}$ Instead, "it was a runaway train." 128 One scholar described Enron as a classic illustration of "gatekeeper failure"129 and stated that "[n]one of the watchdogs that should have detected Enron's collapseauditors, analysts or debt rating agencies-did so before the penultimate moment."130

Enron rose to its place among the hottest companies in the world as quickly as it descended to the depths of "the biggest [bankruptcy] in U.S. history." 131 Investors lost millions of dollars, 132 5,600 employees lost their jobs, pension accounts were decimated, investment bankers and accountants were prosecuted. ${ }^{133}$

The federal government responded to the Enron scandal by passing the Public Company Accounting Reform and Investor Protection Act, also known as the Sarbanes-Oxley Act (SOX). ${ }^{134}$ In addition to enhancing penalties for existing compliance and corporate criminal law violations, SOX imposed several federal corporate governance standards including heightened internal controls, limits on the use of off-balance sheet disclosure, clawbacks of executive compensation for misconduct, and senior executive certification of financial statements. ${ }^{135}$ To mitigate the risk that weak accounting practices could lead to future scandals, SOX requires the CEO and CFO to attest to the accuracy of financial statements, the

125. Wendy Zellner, Jeff Skilling: Enron's Missing Man, Bloomberg Bus. WK. (Feb. 11, 2001), http://www.bloomberg.com/news/articles/2002-02-10/jeff-skilling-enrons-missingman [https://perma.cc/4PQX-Z7PY].

126. Id.

127. Cheryl L. Wade, Corporate Governance Failures and the Managerial Duty of Care, 76 St. Johns L. Rev. 767, 782 (2002).

128. Id.

129. John Coffee, Jr., Understanding Enron: "It's About the Gatekeepers, Stupid”, 57 Bus. LAW 1403, 1405 (2002).

130. Id. at 1408 .

131. Shaheen Pasha \& Jessica Seid, Lay and Skilling's Day of Reckoning, CNN Money (May 25, 2006, 7:35 PM), http://money.cnn.com/2006/05/25/news/newsmakers/enron_verdict/index.htm [https://perma.cc/8HUL-5KVX].

132. Coenen, supra note 116.

133. Vaughn K. Reynolds, The Citigroup and J.P. Morgan Chase Enron Settlements: The Impact on the Financial Services Industry, 8 N.C. BANKING InsT. 247, 247 (2004). Both Citigroup and JPMorgan Chase financed transactions for Enron, which allowed Enron to disguise loans as commodities transactions. Press Release, SEC, SEC Settles Enforcement Proceedings against JPMorgan Chase and Citigroup, (July 28, 2003), http://www.sec.gov/ news/press/2003-87.htm [https://perma.cc/Q5J7-8VTG]. The SEC punished both Citigroup and JPMorgan by having them pay fines of \$101 million and \$135 million, respectively. Former Enron CEO Kenneth Lay and former Enron COO Jeffrey Skilling were both convicted of multiple federal offenses related to the scandal and were found guilty on charges of conspiracy, wire fraud, and securities fraud. Coenen, supra note 116. Arthur Anderson fired the partner in charge of the Enron audits and ultimately collapsed as a result of the scandal. Enron: The Real Scandal, The Economist, (Jan. 17, 2002), http://www.economist .com/node/940091 [https://perma.cc/X4JF-4ZUJ].

134. Sarbanes-Oxley Act of 2002, Pub. L. No. 107-204, §903(a)-(b), 116 Stat 745 (2002).

135. $§ 903(a)-(b)$. 
creation of internal controls, and the appointment of only independent directors to the audit committees of publicly-traded companies. ${ }^{136}$

\section{Excessive Risk-Taking Related Governance Failures}

The recent financial crisis similarly provoked Congressional intervention into the arena of corporate governance. Responding to excessive risk taking by a number of financial market firms during the "real estate bubble"-a period of inflated prices and easy access to credit markets-Congress adopted several structural governance reforms; specifically, Congress imposed obligations on financial market participants to alter board committee composition and to create new board committees.

In 2010, Congress enacted the Wall Street Reform and Consumer Protection Act, also known as the "Dodd-Frank Act."137 The Dodd-Frank Act introduces a significant body of unprecedented reforms that aim to reduce risk in the financial services industry. Title I of the Act creates the Financial Stability Oversight Council comprised of the heads of the following economic and financial markets regulatory leaders: Secretary of the Treasury (chairs the Council); Chairman of the Federal Reserve; Comptroller of the Currency; Director of the Consumer Financial Protection Bureau; Chairperson of the U.S. Securities and Exchange Commission; Chairperson of the Federal Deposit Insurance Corporation; Chairperson of the Commodity Futures Trading Commission; Director of the Federal Housing Finance Agency; the Chairman of the National Credit Union Administration Board; and an independent member (with insurance expertise). ${ }^{138}$

Title II of the Dodd-Frank Act imposes obligations on systemically important financial firms to establish orderly liquidation plans or "living wills." 139 Other provisions in the act aim to reduce risk in various sectors of financial markets. Title IV introduces registration requirements for certain hedge fund advisers and requires certain private equity funds and hedge funds to register with federal regulators. ${ }^{140}$ Title $\mathrm{V}$ offers the first federal financial regulatory efforts to oversee the insurance industry. ${ }^{141}$ Title VI codifies hotly debated rules governing risk-taking by bank holding companies. ${ }^{142}$ Reversing the prohibition against regulatory intervention in the over-the-counter (OTC) derivatives market, Title VII develops a framework for disclosure, clearing and settlement of OTC market transactions. ${ }^{143}$ The clearing and settlement regulations included specific gov-

136. Disclosure Required by Sections 406 and 407 of the Sarbanes-Oxley Act of 2002, 68 Fed. Reg. 5110 (Jan. 31, 2003), http://www.sec.gov/rules/final/33-8177.htm [https:// perma.cc/TN5Y-LVTU].

137. Dodd-Frank Wall Street Reform and Consumer Protection Act, Pub. L. No. 111203, 124 Stat. 1376 (2010).

138. $§ 111(\mathrm{~b})(1)$.

139. $\$ 201$.

140. $\$ \S 401-416$

141. $\$ \S 501-502$.

142. $\$ \$ 701-54$.

143. $\$ \S 701-54$. 
ernance provisions impacting the board and decision-making structure for OTC derivatives clearinghouses.

To preserve the benefits of the corporate governance reforms enacted during the crisis, Congress incorporated several of the corporate governance provisions imposed under the earlier regulation in the Dodd-Frank Act. In an effort to link executive compensation more directly to the performance of the firm, to address disgruntled shareholders' complaints regarding ever-larger executive compensation packages, and to quell the explosive criticism of federal aid to failing financial firms, the Act creates a right for shareholders to have a "say-on-pay." 144 Presumably, by granting shareholders a voice in discussions regarding managers' compensation, Congress empowers shareholders to challenge managers' selfish pursuit of the kind of risk-taking strategies that threaten the long-term health of the firm.

Congress also created a say-on-pay vote giving shareholders the ability to express views on the compensation paid-golden parachutes-to departing executives and directors who are leaving the firm. ${ }^{145}$ To align managers' incentives with shareholders' incentives, federal legislation adopted during the crisis prohibited firms that received federal assistance from making golden parachute payments. ${ }^{146}$ While this kind of arrangement-a golden parachute-is common, contractual provisions that reward departing executives may exacerbate the tension between shareholders' interests and managers' interests.

In addition to say-on-pay and limitations on compensation after departing a firm, new obligations under Regulation S-K require disclosure of the relationship between executives' compensation and the firm's performance, the mean of the annual compensation of all employees, the total annual compensation awarded to the CEO, and the ratio of the CEO's compensation to the median compensation of all employees. ${ }^{147}$ The Dodd-Frank Act also requires companies whose securities trade in public markets to include clawback provisions in executives' contracts. ${ }^{148}$ Clawbacks enable the company to recover incentive-based compensation awarded to any current or former executive officer in the event that the company is required to restate its financial statements because of material noncompliance with applicable financial reporting requirements. ${ }^{149}$

Underscoring the significant monitoring role of the board and the incentives that managers and inside directors may have to take excessive risks to temporarily increase the company's share price and enhance their compensation, the Dodd-Frank Act requires companies subject to the Act to appoint only independent directors to the board's compensation

144. See 26 U.S.C. $\S 280 G(b)(5)(B)$ (2012).

145. Id.

146. Dodd-Frank, § 951.

147. § 953(b).

148. See, e.g., § 954.

149. $§ 954$. 
committee. ${ }^{150}$

Finally, to address concerns regarding risk-taking directly, the DoddFrank Act requires a narrative explanation of compensation policies affecting employees who may have incentives to take risks that may have a material effect on the corporation. ${ }^{151}$ Moreover, large systemically significant financial institutions must create a risk-management committee of the board of directors that oversees risk management on an enterprisewide basis. ${ }^{152}$

The risk-management committee must have a written charter approved by the company's board of directors. ${ }^{153}$ At least one member of the riskmanagement committee must have risk-management expertise "commensurate with the company's capital structure, risk profile, complexity, activities, size, and other appropriate risk-related factors." 154 The chair of the committee must be independent, meaning the chair lacks personal or financial ties to the company. ${ }^{155}$ The risk committee must adopt a riskmanagement framework that sets clear risk limitations, select processes and systems for identifying and reporting risks, and develop effective and timely corrective action policies to address risk deficiencies. ${ }^{156}$ To preserve the independence of the chief risk officer (CRO), the regulations provide for the CRO to report directly to the risk committee and the CEO. ${ }^{157}$ In addition, if companies are subject to Section 165(h), the chair of the board's risk-management committee must be independent. ${ }^{158}$

The Sarbanes-Oxley Act and the Dodd-Frank Act create unprecedented federal interventions into the province of corporate governancethe most intimate decision-making body of publicly-traded corporations. Each of these statutes imposes standards on corporate leadership with the goal of reducing risks related to the operations of corporations. Even more specifically, the reforms aim to mitigate certain kinds of risks, such as misconduct risk and undesirable risk-taking by businesses at the center of commercial transactions-financial institutions. ${ }^{159}$ The core requirements of each statute are designed to ensure that publicly-traded corporations adopt institutional reforms, individual accountability mechanisms, and internal controls.

150. $\S 952$. Prior to the adoption of the Dodd-Frank Act, however, federal corporate governance reforms already required certain reporting companies to create audit committees composed of only independent directors. Id. In addition, preexisting regulations require companies whose equity securities are publicly traded to elect independent directors to a majority of the seats on the board. $I d$.

151. $§ 953$.

152. $§ 165(\mathrm{~h})$.

153. Id.

154. Id.

155. Id.

156. $I d$.

157. Id.

158. Id.

159. Johnson, supra note 7, at 191. 


\section{Alternative Rationales}

While enhanced performance or better governance offer important rationales for gender diversity on corporate boards, an important question dominates any relevant analysis; do we sufficiently understand how boards and the senior executives endeavor to mitigate undesirable risks? A survey of the literature illustrates how firm oversight and the management of a diversity of risks are core concerns for every business and uniquely troubling concerns for financial market firms. Careful consideration reveals that risk management may offer the most important rationale for gender diversity on corporate boards.

Behavioral economics describes a series of challenges that relate to the overarching decision-making structure within corporations and the inherent limitations of the individual people who participate in governance. ${ }^{160}$ Behavioral economics introduces an interdisciplinary analysis that examines the rudimentary assumptions in economic theory. Borrowing from psychological literature, for example, behavioral economics explores collective decision-making dynamics. ${ }^{161}$

Group decision-making processes create a fertile ground for a number of concerns. "Groupthink," for example, describes a psychological phenomenon that occurs when people work together in groups in an environment that emphasizes unanimity, cohesiveness, and consensus. ${ }^{162}$ Groupthink is "a mode of thinking that people engage in when they are deeply involved in a cohesive in-group, when the members' striving for unanimity overrides their motivation to realistically appraise alternative courses of actions." 163 Groupthink occurs when the dominant sentiment in decision-making is concurrence-seeking. ${ }^{164}$

Several other challenges plague boards making group decisions. Confirmation, ${ }^{165}$ structural, ${ }^{166}$ and relational biases and overconfi-

160. Langevoort, supra note 33 , at $810-11$.

161. Id. at 826-27.

162. Irving L. JANis, Victims of Groupthink 9 (1972). For a careful application of the psychology literature to corporate board dynamics, see Bainbridge, supra note 35, at 32.

163. Janis, supra note 162 , at 9.

164. Irving L. Janis, Group Think, Psychology Today in Readings in Managerial Psychology 432, 433 (Harold J. Leavitt et al., eds., 1980).

165. As psychological literature explains, confirmation bias inhibits board members' ability to objectively evaluate information presented to the board. Individuals process information, seek data, and understand outcomes based on their subjective, intuitive beliefs. Consequently, boards engage in selective information gathering and view certain information, such as the information distributed by senior executives, with great deference. See Macroprudential Regulation, supra note 2; see also Douglas G. Baird \& Robert K. Rasmussen, The Prime Directive, 75 U. Cin. L. Rev. 921, 936 (2007).

166. Relational and structural bias develop from favorable perceptions because of board members shared educational or professional background, economic, social or other personal affiliations. Relational and structural biases lead board members to under-examine the mistakes of colleagues or view their accomplishments in an overly generous manner. See Antony Page, Unconscious Bias and the Limits of Director Independence, 2009 U. Ill. L. Rev. 237, 249-50 (2009); see also Julian Velasco, Structural Bias and the Need for Substantive Review, 82 WASH. U. L.Q. 821, 824 (2004) (explaining that "the term 'struc- 
dence ${ }^{167}$ may also impede group decision-making. ${ }^{168}$ Social psychological theory also discusses group dynamics inside boardrooms and "predicts that individuals who have majority status have the potential to exert a disproportionate amount of influence in group decisions." 169 This survey is, however, merely a sampling of the limitations that cognitive biases create. What does the evidence suggest regarding the impact of gender diversity on group dynamics and risk management outcomes?

Managing risks related to cognitive bias lies at the heart of risk oversight for most businesses. The introduction of contrarian perspectives and more collaborative decision-making processes markedly improves risk management oversight in businesses. ${ }^{170}$ Evidence suggests that increasing the number of women directors enhances board discussion, initiates productive debate, and mitigates deference to the dominant perspectives advanced by senior managers. ${ }^{171}$ As one scholar notes, "[p]erhaps, then,

tural bias' generally refers to the prejudice that members of the board of directors may have in favor of one another and of management").

167. Overconfidence may result in boards agreeing to policies that permit employees to adopt excessively optimistic understandings of data. See Langevoort, supra note 32, at 803 . In boards, directors may exhibit an inappropriate level of confidence regarding senior executives or other board members' abilities. Bainbridge, supra note 35, at 29. Failing to acknowledge fellow board members' limitations will lead to overconfidence in their conclusions, projections, and suggestions regarding corporate decisions. Id. at 30. Another concern is the threat of herd effects. In certain business models and most certainly among financial institutions' senior executives, boards and rank-and-file employees are engaged in activities at the unique intersection of important financial market risks and decision-making influenced by cognitive limitations. Liquidity and solvency crises in financial institutions may be incited or exacerbated by herd behavior-a dynamic whereby decisionmakers rely on the decisions of others rather than just their own information. $I d$. at 30 . Commentators note that the financial crisis was an instance of "herd-effects" and selfreinforcing judgments derived solely from the judgments of others. Id. at 28 .

168. See Johnson, supra note 165, at 897 n. 103. Confirmation bias inhibits searching inquiries and often means that board decisions fail to face the scrutiny that such important questions deserve. See Melanie B. Leslie, The Wisdom of Crowds? Groupthink and Nonprofit Governance, 62 FLA. L. REv. 1179, 1201-02 (2010).

169. Ruth Mateos de Cabo et al., Gender Diversity on European Banks' Boards of Directors, 109 J. Bus. ETHics 145, 148 (2012).

170. See generally Kristin N. Johnson, Addressing Gaps in the Dodd-Frank Act: Directors' Risk Management Oversight Obligations, 45 U. Mich. J.L. Reform 55 (2011).

171. One study inquires:

Do women add unique value to the boardroom ... ? Absolutely. They provide unique perspectives, experiences, and work styles as compared to their male counterparts. The addition of women to the boardroom, for example, can greatly enhance the board's deliberations. Women's communication styles tend to be more participative and process-oriented. These stylistic differences may enhance directors' decision-making processes by encouraging the board to consider a wider range of strategic options. Women's different experiences and perspectives may also help the board consider a wider variety of customer needs and interests. Just over half of the US population is female and women account for the majority of US consumer purchases. Who better, then, than a female board member to offer insights on the female customer?

Catherine M. Daily \& Dan R. Dalton, Women in the Boardroom: A Business Imperative, 24 J. Bus. Strategy 8, 9 (2003). See also Morten Huse \& Anne G. Solberg, Gender Related Boardroom Dynamics: How Women Make and Can Make Contributions on Corporate Boards, http://www.boeckler.de/pdf/v_2006_03_30_huse3_f5.pdf [https://perma.cc/ F4NY-5JYT] ("Gender influences cognition as well as behaviour."); Nielsen \& Huse, supra 
women, qua women, are inherently or consistently different from men in ways that impact the objectives and operations of corporate boards of directors." ${ }^{172}$ Enhancing the deliberative process offers a critical pathway toward defeating the intractable confirmation, relational, and structural biases that generally characterize group decision-making, and, more specifically, impact board or senior executive decision-making.

Empirical evidence provides some guidance regarding the investment decisions that are at the core of financial institutions' business model. A recent survey suggests that "[m]en and women invest differently" and, that "in at least one respect, women may be better at it." ${ }^{173}$ In 2010, Vanguard examined the investment decisions of 2.7 million individuals with I.R.A.s; the study found that during the crisis of 2008 and 2009, "men were much more likely than women to sell their shares at market lows" and experience big losses. ${ }^{174}$ Another study explored the trading habits of men and women and concluded that overconfident men trade securities more frequently than women and men incur losses because of their excessive trading. ${ }^{175}$ Some studies highlight neuroscience research and suggest that there may be correlations between testosterone levels and risktaking. ${ }^{176}$

These studies also intimate that women tend to be more conservative and risk averse than men. ${ }^{177}$ Supplementing the empirical studies that explore whether changing board composition improves financial performance, an interdisciplinary scholarship demonstrates that the relationships among board members significantly influences corporate governance.

While claims in favor of gender diversity on corporate boards frequently raise arguments related to the strengths that women bring to groups as directors or employees, ${ }^{178}$ firms must understand the limita-

note 97 , at 143 (finding that "women on boards influence key board processes, which in turn enhance or inhibit board effectiveness in strategic and operational control."); Chris Bart \& Gregory McQueen, Why Women Make Better Directors, 8 InT'L J. Bus. GovernANCE \& ETHICS 93, 96-97 (2013).

172. Heminway, supra note 101, at 79 (emphasis in original).

173. Jeff Sommer, How Men's Overconfidence Hurts Them as Investors, N.Y. TIMES (Mar. 13, 2010), http://www.nytimes.com/2010/03/14/business/14mark.html?_r=0 [https:// perma.cc/AZ5X-XQ37]; see also John Ameriks, Jill Marshall, \& Liqian Ren, Equity Abandonment In 2008-2009: Lower Among Balanced Fund Investors, http://pressroom.vanguard .com/nonindexed/Equity_abandonment_in_2008_to_2009.pdf [https://perma.cc/G8G3$\mathrm{C} 4 \mathrm{MN}]$.

174. Steve Bluen, Talent Management in Emerging Markets (2013); see also Ameriks et al., supra note 173.

175. Brad M. Barber \& Terrance Odean, Boys Will Be Boys: Gender, Overconfidence, and Common Stock Investment, Q. J. Econ., 261, 277-78 (2000).

176. Sommer, supra note 173. There is evidence that women's behavior on boards follows the stereotypical assumptions regarding how they would behave. Id.

177. Irwin P. Levin et al., The Interaction of Experimental and Situational Factors and Gender in a Simulated Risky Decision-Making Task, 122 J. Psychol. 173-180 (1988) (finding that women students were more risk averse than male students in experimental setting).

178. Regina F. Burch, Worldview Diversity in the Boardroom: A Law and Social Equity Rationale, 42 Loy. U. CHI. L.J. 585, 603 (2011). See generally Lisa M. Fairfax, The Bottom Line on Board Diversity: A Cost-Benefit Analysis of the Business Rationales for Diversity 
tions of our best learning on cognitive bias and the impact of gender diversity on group decision-making. ${ }^{179}$ Gender diversity is not a panacea that overcomes homogeneity and introduces the heterogeneity associated with better group decision-making; successful implementation of board diversity strategies requires a thoughtful exploration of the specific talent, background, unique perspective, and experience that women bring to the executive suite or boardroom.

If the benefits of gender diversity rest on women acting differently than men or having different ideas, what happens when women begin to conform their behavior and ideas to dominant sentiments on the board? ${ }^{180}$ To draw the conclusion that women will be valuable, we assume that women will not conform to groupthink or herd behavior and will continue to act independently and reflect the attributes that bring contrarian benefits. The studies exploring these questions are inconclusive.

According to one set of studies, women are tougher monitors. ${ }^{181}$ The board's role as a monitor of managers is a fundamental concept of agency theory. ${ }^{182}$ Agency theory suggests that a diverse board frequently increases board independence, which in turn increases the board's ability to monitor the management. ${ }^{183}$ However, even though more efficient monitoring of management might have a positive impact on firm financial performance, agency theory provides no clear link between board diversity and firm financial performance. ${ }^{184}$

If decision-making renders corporate boards susceptible to the pressures of structural dynamics and cognitive biases, ${ }^{185}$ the securities, commodities, and financial product structuring processes suggest that financial institutions' senior executives, boards, and rank-and-file employees-influenced by cognitive biases-may engage in trading activities at a unique intersection of important financial market risks and decisionmaking. We have seen, for example, the effects of herd behavior in financial markets-a dynamic whereby decision-makers rely on the decisions of others rather than just their own information may lead to many market participants having highly correlated risk exposure. ${ }^{186}$ The next Part argues that financial markets and the many constituencies impacted by

on Corporate Boards, 2005 Wis. L. Rev. 795 (2005); Melissa Murray \& Darren Rosenblum, Should Job Creation Favor Men?: On Equity in Economic Stimulus, S.F. CHron. (May 19, 2009, 4:00 AM), http://www.sfgate.com/opinion/article/Should-job-creation-favormen-3297786.php [https://perma.cc/R9DA-VRCB].

179. Heminway, supra note 102 , at 79.

180. See, e.g., Sharpe, supra note 45 , at 1114.

181. See Adams \& Ferreira supra note 90, at 293 ("our results suggest that genderdiverse boards are tougher monitors.").

182. See The Gender and Ethnic Diversity of US Boards and Board Committees and Firm Financial Performance, supra note 19, at 399.

183. Id.

184. Id.

185. Scotland M. Duncan, The Empirics of Governance and Fraud, 70 U. PITT. L. REV. 465, 476 (2009).

186. See Abhijit V. Banerjee, A Simple Model of Herd Behavior, 107 Q. J. Econ. 797, 800 (1992) (finding that herd behavior may explain asset price volatility). 
their operations may benefit from exploring whether enhancing gender diversity may mitigate the perils of risk management concerns.

\section{WOMEN ON CORPORATE BOARDS: A STRATEGY FOR IMPROVING RISK OVERSIGHT}

A burgeoning literature explores whether focusing on a single component of firm performance (risk management oversight) in a specific industry (financial markets) reveals important insights regarding the benefits of gender diversity. Focusing on this narrow intersection-gender diversity in leadership and risk management oversight at financial institutions-may introduce an important mechanism for managing excessive risk in financial markets and engender renewed interest in exploring the benefits of gender diversity on corporate boards.

\section{A. Empirical Evidence on Women and Risk Management in Financial Institutions}

While a plethora of empirical studies have examined the benefits or costs of gender and racial or ethnic diversity on corporate boards, ${ }^{187}$

187. See Heminway, supra note 101 , at 79 . (arguing that increasing the number of women on boards could enhance diversity because "[r]esearch offers evidence that women may bring game-changing perspectives and proficiencies to the boardroom."); Lisa M. Fairfax, Board Diversity Revisited: New Rationale, Same Old Story?, 89 N.C. L. Rev. 855, 855 (2011) (generally challenges the reliance on business rationales to justify increased board diversity and "insists that diversity advocates must pay greater attention to the role of social and moral justifications in the effort to diversify the corporate boardroom."); Lissa Lamkin Broome \& Kimberly D. Krawiec, Signaling Through Board Diversity: Is Anyone Listening?, 77 U. CIN. L. REv. 431, 432-33 (2008) ("Of particular interest has been research on the impact, if any, of board diversity on corporate performance. Recent quantitative studies primarily test for a relationship between board diversity and various measures of corporate performance . . . some studies find evidence that . . . board diversity positively affects firm performance. Other studies, however, find no support for this theory."); see generally Fairfax, supra note 99, at 593 (summarizing the empirical data addressing impact of diversity in the boardroom); Donald C. Langevoort, Overcoming Resistance to Diversity in the Executive Suite: Grease, Grit, and the Corporate Promotion Tournament, 61 WAsh. \& LeE L. Rev. 1615, 1642 (2004) ("The point here goes back to my metaphor of the firm as a nexus of negotiations. The promotion of diversity may or may not hold a position of power within the firm. If I am right [about potential costs] its power rare ly will be great. Simple demands of adherence because of the rightness of the cause are unlikely to provoke a cooperative response among those who disagree on (perhaps self-serving) principled grounds."); Steven A. Ramirez, Games CEOs Play and Interest Convergence Theory: Why Diversity Lags in America's Boardrooms and What to Do About It, 61 WAsH. \& LeE L. Rev. 1583, 1613 (2004) ("CEOs play the game of homosocial reproduction when selecting directors .... But, because board diversity can improve corporate governance, racial reformers may find many allies ... in this arena.").

For empirical discussion, see Credit Suisse, Research Institute, The CS Gender 3000: Women in Senior Management 3 (2014) ("greater diversity in boards and management are empirically associated with higher returns on equity, higher price/book valuations and superior stock price performance"); Miller \& Triana, supra note 85 , at 755 (finding that between 2002 and 2005, Fortune 500 firms with gender and racial diversity on boards performed better than non-diverse firms and finding that the link can be explained through innovation and firm reputation); Corporate Governance, Board Diversity, and Firm Value, supra note 13, at 51 ("After controlling for size, industry, and other corporate governance measures, we find statistically significant positive relationships between the presence of women or minorities on the board and firm value."). 
there is a dearth of literature examining the value of greater gender or ethnic diversity in risk management oversight. ${ }^{188}$ There is a sizeable gap in the empirical literature exploring the significance of gender diversity in risk management. The available studies, however, offer a compelling window into the potential benefits that gender diversity may bring to risk oversight. Coupling the behavioral economics literature and the literature exploring the impact that gender diversity may have on boards reveals a new pathway for enhancing governance of risk within a corporation.

In the years following the recent financial crisis, scholars have published several empirical studies that examine the effects of gender diversity in leadership at financial institutions. A recent study by Andre Chanavat and Katherine Ramsden used Thomson Reuters' proprietary analysis of 250 performance indicators in a dataset of 4,100 public companies around the world distinguishing among them by industry and region. The study found that "[c]ompanies with no women on their boards . . . had slightly higher tracking errors, indicating potentially more volatility." 189 The study does not resolve the question whether gender diversity militates toward better risk management, but the data may offer interesting insights into the relationship between greater gender diversity and risk management.

188. Within the literature exploring gender diversity, there are many articles examining the general impact of gender diversity on corporate boards. See, e.g., Jiekun Huang \& Darren J. Kisgen, Gender and Corporate Finance: Are Male Executives Overconfident Relative to Female Executives?, 108 J. FIN. EcON. 822, 822 (2013) (finding that "[m]ale executives undertake more acquisitions and issue debt more often than female executives" and that female executives give earnings guidance with wider ranges); Mara Faccio et al., $C E O$ Gender, Corporate Risk-Taking, and the Efficiency of Capital Allocation, 39 J. CorP. FIN. (June 15, 2015), http://papers.ssrn.com/sol3/papers.cfm?abstract_id=2021136 [https://perma .cc/34Y5-8B4M] ("We document that firms run by female CEOs tend to make financing and investment choices that are less risky than those of otherwise similar firms run by male CEOs."). There are fewer articles, however, expressly examining women leaders' impact on risk oversight at financial institutions. See Laura St. Claire, et al., Braving the Financial Crisis: An Empirical Analysis of the Effect of Female Board Directors on Bank Holding Company Performance 1 (Office of the Comptroller of the Currency, Working Paper No. 2016-1, 2016), https://www.occ.gov/publications/publications-by-type/occ-working-papers/ 2016-2013/working-paper-2016-1.html [https://perma.cc/X8H4-MK76]; see also Ajay Palvia et al., Are Female CEOs and Chairwomen More Conservative and Risk Averse? Evidence from the Banking Industry During the Financial Crisis, 131 J. Bus. EтніCs 577, 592 (2015) ("From a public policy perspective, the documented benefits of female leadership for bank stability may be of interest to regulators when setting future policies for promoting gender equality and the advancement of women in business."); See generally Thorsten Beck et al., Gender and Banking: Are Women Better Loan Officers?, 17 Rev. Fin. 1279 (2015); Maureen I. Muller-Kahle \& Krista B. Lewellyn, Did Board Configuration Matter? The Case of US Subprime Lenders, 19 Corp. Governance: An InT'L. Rev. 405, 405 (2011); Mateos de Cabo et al., supra note 169, at 145; Andrea Bellucci et al., Does Gender Matter in BankFirm Relationships? Evidence from Small Business Lending, 34 J. Fin. \& BANKING 2968 (2010).

189. André Chanavat \& Katharine Ramsden, Mining the Metrics of Board Diversity, THOMSON Reuters (2013), http://share.thomsonreuters.com/pr_us/gender_diversity_white paper.pdf [http://perma.cc/7SBF-762R]. Tracking error describes the difference between a portfolio's returns and an identified benchmark or index. The difference indicates the level of active risk in the portfolio. 
In 2014, the authors of the study Are Female CEOs and Chairwomen More Conservative and Risk Averse? Evidence from the Banking Industry During the Financial Crisis, presents a more compelling case for the relationship between female leadership for bank stability. ${ }^{190}$ The study examined whether bank capital ratios and default risk are associated with the gender of the bank's CEO and Chairman of the board. The authors hypothesized that "female CEOs and board Chairs should assess risks more conservatively, and thereby hold higher levels of equity capital and reduce the likelihood of bank failure during periods of market stress."191 The study used a panel of U.S. commercial banks to evaluate their presumptions and concluded that banks with female CEOs tended to hold more conservative levels of capital after controlling for the bank's asset risk and other attributes. The study also found that, "while neither CEO nor Chair gender is related to bank failure in general" there is "strong evidence that smaller banks with female CEOs and board Chairs were less likely to fail during the financial crisis."192

A study published by the senior members of the Office of the Comptroller of the Currency in March 2016-Braving the Financial Crisis: An Empirical Analysis of the Effect of Female Board Directors on Bank Holding Company Performance (Braving the Financial Crisis) - provides the most critical insights to date regarding the significance of the relationship between gender diversity and risk management in the financial services industry. ${ }^{193}$ Braving the Financial Crisis reflects the findings of a unique dataset of board director demographic data gathered from publicly available information filed with the U.S. Securities and Exchange Commission (SEC) in the relevant companies' definitive proxy statements. ${ }^{194}$ The study examined the largest U.S. bank holding companies from 1994-2014-a group that consists of fifty-five of the largest ninety publicly-traded bank holding companies during this period as measured by total assets. ${ }^{195}$ The model ${ }^{196}$ adopted in the study establishes several important conclusions; ${ }^{197}$ yet, the findings of the study introduce a watershed revelation in the literature exploring the benefits of gender diversity.

190. See Palvia et al., supra note 188 , at 577.

191. See id.

192. See id.

193. See St. Claire, et al., supra note 188.

194. The proxy statements were filed on Form DEF 14A (DEF 14A). Id. at 2.

195. The fifty-five bank holding companies in the study reflect approximately $63 \%$ of the banking industry's total assets. $I d$.

196. The model measures bank holding company performance based on Tobin's Q, which reflects the ratio of a firm's market value to replacement value of the firm's assets. Renée B Adams \& Hamid Mehran, Bank Board Structure and Performance: Evidence for Large Bank Holding Companies, 21 J. Fin. Intermediation 243, 250 (2012).

197. The research carefully explores whether "a specific number of women," also described as a critical mass, "is needed to have an effect on group decision making." St. Claire, et al., supra note 188. Several of the earlier discussed studies also explored whether "a critical mass," often identified as three women, has an influence on board decision making. Acknowledging that "the direct relationship between board gender diversity and performance is still unclear," the Braving the Financial Crisis study finds that a critical mass of women on boards: 
According to the study, during the period of the financial crisis (2008-2012) the number of female directors serving on boards positively influenced the performance of bank holding companies. ${ }^{198}$ The authors conclude that bank holding companies with at least three female directors "braved the crisis better."199

Braving the Financial Crisis prompts a number of questions. One might inquire whether greater gender diversity may provide a valuable tool for mitigating excessive risk-taking. These inquiries also encourage further studies that explore whether gender diversity compliments any particular risk management methods. We might also ask whether factors beyond board composition likely influence board governance at firms that had better financial performance or risk management oversight. Finally, which cultural norms impact risk oversight at firms that demonstrate greater risk management capabilities? The next Section introduces a few of these questions. At such an early moment in the exploration of the impact of gender diversity on financial institution risk management oversight, posing questions for empirical investigation may offer the best path toward financial market stability.

\section{B. Evidence Demonstrating Effective Use of Risk Management Tools}

While general observations regarding gender diversity and financial firm performance present insights that may be important for certain stakeholders, for scholars carefully dissecting the recent financial crisis for guidance on the best methods for mitigating systemic risk, ${ }^{200}$ these studies provide a pathway for creating good governance and well-tailored regulatory reforms.

\section{Conventional Risk Management Tools}

Risk management tools enable financial institutions to identify risks

$[\mathrm{H}]$ as consistently increased the effectiveness of women in leadership roles. The magic number 3 signifies that within a male-dominated group, a critical mass of at least three women must be reached in order for those women to Id. at 6 . have a significant impact on group decision-making (citations omitted).

198. Id. at 13 .

199. Id. at 24. Looking at performance over the entire test period, however, the results are not consistent. The performance of bank holding companies with at least three female directors was not statistically different from the firms with fewer women directors when one examines the performance for the entire span of the study. Id. The authors also noted that the performance of bank holding companies "with at least two female directors on average showed significantly lower performance." Id.

200. See Kristin N. Johnson \& Steven A. Ramirez, New Guiding Principles: Macroprudential Solutions to Risk Management Oversight and Systemic Risk Concerns, 11 U. ST. Thomas L.J. 386, 426 (2014); Johnson, supra note 165, at 903-04; Iman Anabtawi \& Steven Schwarcz, Regulating Systemic Risk: Towards an Analytical Framework, 86 NoTRE Dame L. Rev. 1349, 1351 (2011); Steven L. Schwarcz, Systemic Risk, 97 Geo. L. J. 193, 204 (2008). 
and adjust investment and trading strategies to account for risks. ${ }^{201} \mathrm{Em}$ pirical studies have applauded women directors and senior executives for employing one of the oldest and most common methods of preventing a liquidity or solvency crisis at an individual financial institution- maintaining conservative levels of capital. ${ }^{202}$

A 2015 study of 6,729 banks offers critical evidence that banks with women CEOs or board chairmen held more conservative levels of capital after controlling for, among other attributes, the risks in the bank's asset portfolio, the size of the bank, and the economic conditions in the bank's state. ${ }^{203}$ The authors of the study found that the "observed differences in capital ratios are economically significant and indicate that female-led banks hold about 5-6\% more capital than male-led banks." 204 Banks that maintain more conservative levels of capital had greater capacity to endure an economic shock and, to the extent a crisis materializes, a prolonged period of economic decline. An empirical study of Australian firms similarly concluded that "greater gender diversity moderate[d] excessive firm risk which in turn improve[d] firms' financial performance." 205

Insolvency occurs if a financial institution lacks sufficient capital to satisfy its outstanding debts. Systemic risk may result from a large, complex financial institution becoming insolvent and triggering a domino effect of losses as the financial institution defaults on contracts with other financial institutions. $^{206}$ Multiple insolvencies within the industry could lead to a prolonged period of economic stagnation or an economic depression. While a healthy risk appetite is important for strong performance in the long run, an appropriate level of risk aversion during an economic downturn may prevent solvency crises.

\section{Governance as a Risk Management Tool}

As noted in Part I, state and federal regulators increasingly resort to corporate governance measures to implement risk oversight policies. Specifically, evidence demonstrates that women enhance board leadership by attending board meetings more frequently and engaging in committee service. ${ }^{207}$ Women are more likely to participate in the monitoring activi-

201. Johnson \& Ramirez, supra note 200 , at 426 ; Johnson, supra note 170 , at $71-72$ (describing risk management failures of various firms and subsequent solvency crises during the period 2007-2011).

202. See, e.g., Palvia et al., supra note 188, at 606 (finding that "banks with female CEOs are more conservative and hold higher levels of equity capital after controlling for the bank's asset risk and other attributes.").

203. Id.

204. Id.

205. Marion Hutchinson et al., Who Selects the 'Right' Directors? An Examination of the Association Between Board Selection, Gender Diversity and Outcomes, 55 Acct. \& Fin. 1071, 1071 (2015).

206. See Schwarcz, supra note 200, at 198-200.

207. According to one study, women directors, on the other hand, are significantly less likely to have attendance issues than their male counterparts. The Adams and Ferriera study asks several questions, including whether "board inputs (director attendance and 
ties associated with boards. ${ }^{208}$ Coupling these findings with federal efforts to achieve stronger monitoring suggests that a greater number of women on corporate boards may improve risk management oversight.

Section 165(h) of the Dodd-Frank Act obligates large, complex financial institutions to appoint a risk management expert to the board of directors. ${ }^{209}$ Noting the results of studies examining the impact of gender diversity on risk oversight, financial institution boards should evaluate gender diversity in leadership as a potential risk management tool. While Part IV explores voluntary experimentation with board and leadership diversity, this Section describes a few of the empirical studies that examine this critical link.

In a study by the U.S. Department of Housing and Urban Development (HUD), Professors Muller-Kahle and Lewellyn examine board diversity in the subprime lending market. ${ }^{210}$ The HUD study demonstrates that lenders with greater gender diversity on their boards were less likely to engage in subprime lending. ${ }^{211}$ Other studies examining the lending market during the crisis inquire as to whether the participation of female loan officers militates against entering into loans with higher default rates. $^{212}$

committee assignments) vary with gender diversity. . . . [whether] the gender composition of the board affect[s] measures of governance, such as chief executive officer (CEO) turnover and compensation" and ultimately, whether "the effect of gender diversity on governance matter[s] sufficiently to affect corporate performance"). Adams \& Ferriera, supra note 90, at 292. Adams and Ferreira find that "gender diversity in boards has significant effects on board inputs." Id.

208. Adams and Ferreira explain that:

Women appear to behave differently than men with respect to our measure of attendance behavior. Specifically, women are less likely to have attendance problems than men. Furthermore, the greater the fraction of women on the board is, the better is the attendance behavior of male directors. Holding other director characteristics constant, female directors are also more likely to sit on monitoring-related committees than male directors. In particular, women are more likely to be assigned to audit, nominating, and corporate governance committees, although they are less likely to sit on compensation

Id. committees than men are.

209. Enhanced risk management figured prominently in the Dodd-Frank Act. See, e.g., Dodd-Frank Act $\$ 165(h)(3)(A)$.

210. Muller-Kahle \& Lewellyn, supra note 188, at 405.

211. Id.

212. See, e.g., Bellucci et al., supra note 188, at 2968; Muller-Kahle \& Lewellyn, supra note 188 at 406 ("Many point to subprime mortgage defaults in the United States as being the key trigger to the global financial crisis that began in 2007 (Duchin, Ozbas, \& Sensoy, 2010). Subprime loans are defined as "loans granted to borrowers with low credit ratings" (Piskorski, Seru, \& Vig, 2010:370). Recent reports estimate that 3.6 million homeowners in the US will have to foreclose on their homes because they are unable to meet their loan obligations (Simon, 2010). As of 2008, US financial institutions are facing estimated losses of up to $\$ 300$ billion as a result of their subprime lending (Sherman \& Tana, 2008). The collapse of the subprime market and the subsequent financial shock that rippled across global markets can be attributed to a combination of factors, but has its roots in risky US mortgage lending practices (Wolf, 2010). Clearly, if the global financial crisis can be compared to an earthquake, subprime lending is at the epicenter."). 
In the context of the risk of financial restatements, a study designed using a matched-pair sample of restatement and control firms and employing conditional logistic regressions to compare the characteristics of restatement and control firms found a significant reduction in the likelihood of financial restatement when the board included at least one female board director. ${ }^{213}$ The empirical evidence suggests that gender diversity inspires different and possibly more innovative approaches to risk management. For several decades, empirical scholars have examined the distinctions between how men and women approach risk. ${ }^{214}$

The evidence demonstrates that women are often more conservative. $^{215}$ Women often demonstrate a lower tolerance for risk than men. ${ }^{216}$ While risk aversion is likely desirable during an economic downturn, it is noteworthy that the same approach would not be optimal in a period of prosperity. Perhaps more importantly, the evidence draws general conclusions that would vary based on many factors. Ensuring appropriate attitudes toward risk may require financial institutions to focus on cultivating a culture of mindful risk oversight among the most senior executives and board members and even within the rank-and-file employees of the firm.

\section{Culture as a Risk Management Tool}

In Better Bankers, Better Banks, Claire Hill and Richard Painter describe the economic, political, sociological, and technical developments that transform the business model of investment banking. ${ }^{217}$ Characterizing the casino culture of Wall Street investment banks in the 1990s, Hill and Painter describe the rise and fall of several storied investment banks. ${ }^{218}$ As Hill and Painter explain, banks like Salomon Brothers experienced the high of having "a gold-plated brand name" in a corner of the financial market and, later, suffered embarrassing losses and a firesale distribution of their assets. ${ }^{219}$ What led to the decline of fabled financial institutions or other prominent market participants in the most recent crisis and past decades? In many instances, financial institutions' culture

213. Lawrence J. Abbott et al., Female Board Presence and the Likelihood of Financial Restatement, 26 Acct. Horizons 607, 626 (2012).

214. See, e.g., John Watson \& Mark McNaughton, Gender Differences in Risk Aversion and Expected Retirement Benefits, 63 Fin. Analysts J. 52, 60 (2007) ("Considerable psychological evidence suggests that women are generally more risk averse than men ... and the results of this study indicate that this heightened risk aversion influences the superannuation/retirement investment choices women make.").

215. Rachel Croson \& Uri Gneezy, Gender Differences in Preferences, 47 J. Econ. LITIG. 448, 449 (2009).

216. Watson \& McNaughton, supra note 214, at 60 ("Considerable psychological evidence suggests that women are generally more risk averse than men . . . and the results of this study indicate that this heightened risk aversion influences the superannuation/retirement investment choices women make.").

217. Claire Hill \& Richard Painter, Better Bankers, Better Banks 73-107 (University of Chicago Press 2016).

218. Id.

219. Id. at 99. 
served to undermine strategic investment decisions. ${ }^{220}$ The rise of obscenity, as Hill and Painter's colorful narrative illustrate, reflected "an ethos in which investment bankers' risk taking served as a proxy for their masculinity."221

Management literature also examines the impact of gender diversity on ethics and compliance concerns.222 One empirical study examining the impact of gender diversity in fostering compliant culture concluded that gender diversity reduces the likelihood and severity of fraud.223 According to the literature, the participation of more senior women and board members introduces a culture in which ethics and compliance receive greater priority. ${ }^{224}$ Studies also indicate that firms with women CEOs typically take more conservative approaches to accounting and their firms are less likely to have to suffer the consequences of earnings restatements ${ }^{225}$ or accounting restatements. ${ }^{226}$

Culture is a thread woven throughout the fabric of a financial institution. When boards and senior management emphasize adopting highly ethical practices and complying with internal policies and externally imposed guidelines, regulation, and legal standards, financial institutions tend to experience less fraud, theft, or other types of misconduct.

\section{DIVERSIFYING STRATEGIES TO MITIGATE RISK EXPOSURE}

Thinking beyond enhanced performance or risk management oversight, alternative incentives may inspire financial institutions to embrace greater gender diversity on boards. The stakeholders may have divergent perspectives regarding gender leadership diversity. Institutional shareholders, for example, may represent diverse constituencies who assign

220. To illustrate the link between masculinity and the culture at firms like Salomon Brothers, Hill and Painter draw upon a common term used on bond trading desks for a star trader-"big swinging dick." Id.

221. Id.

222. See, e.g., Steven A. Ramirez, Diversity, Compliance, Ethics \& In-House Counsel, 48 U. Tol. L. Rev. 465 (2017).

223. Douglas Cumming et al., Gender Diversity and Securities Fraud, 58 Acad. Mgmt. J. 1572, 1573 (2015) (examining gender diversity on boards and securities fraud in China); see generally Douglas Cumming, et al., Listing Standards and Fraud, Managerial \& DECISION ECON. (Mar. 31, 2013), http://papers.ssrn.com/sol3/papers.cfm?abstract_id=2242449 [https://perma.cc/F9TK-J6TV]

224. See, e.g., William A. Weeks et al., The Effects of Gender and Career Stage on Ethical Judgment, 20 J. Bus. Eтнісs 301, 307 (1999); Leslie M. Dawson, Ethical Differences Between Men and Women in the Sales Profession, 16 J. Bus. Eтнісs 1143, 1151 (1997).

225. Simon S.M. Ho et al., CEO Gender, Ethical Leadership, and Accounting Conservatism, 127 J. Bus. Eтнісs 351, 366 (2015) ("Regardless of the measure of conservatism, . . . we find consistent evidence that companies with female CEOs report earnings more conservatively.").

226. Abbott et al., supra note 213, at 626 ("Using a matched-pair sample of restatement and control firms, we conducted conditional logistic regressions comparing the characteristics of restatement and control firms. Briefly, we find a significant reduction in the likelihood of financial restatement and the presence of at least one female board director."). As always, the authors acknowledge issues related to possible omitted variables and the direction of causation. Id. at $626-27$. 
priority to greater gender diversity. Legal standards may emphasize careful consideration of gender diversity when appointing senior executives or board members. This Part presents evidence of internal and external pressures that may motivate financial institutions to enhance gender diversity including corporate shareholder proposals, civil rights litigation and derivative litigation that underscores risk management oversight as a fiduciary duty of financial institution boards.

\section{A. Institutional Investors, Shareholder Proposals, And BoArd Diversity Initiatives}

Shareholders or investors own equity shares in a corporation. Bylaws adopted by shareholders typically detail the rights that accompany an equity investment in a corporation. 227 While shareholders often gain many benefits from corporate ownership, shareholders rarely participate in the day-to-day affairs of the corporation. ${ }^{228}$ The delegation of authority over significant corporate policies to the boards of directors and daily decisions to senior executives often leaves shareholders with a limited voice in governance. ${ }^{22}$ In recent years, however, institutional shareholders who own large percentages of a single corporation's shares or who have played a critical role in the early fundraising of a corporation (angel investors or venture capitalists) increasingly exert significant influence over the internal affairs of corporations. ${ }^{230}$

Institutional investors have increasingly begun to signal that they expect corporations to take greater steps to improve board diversity. A number of high-profile examples illustrate the marked influx of institutional investors' shareholder proposals seeking to promote board diversity. California State Teachers' Retirement System (CalSTRS), ${ }^{231}$ for example, has led a sustained campaign to raise awareness of board diversity as a key investing principle. Over the last several years, CalSTRS has incorporated language in its Global Principles of Accountable Corporate Governance that implores corporate boards to establish and disclose nomination policies that "address historically underrepresented groups on the board, including women and minorities." 232

227. See, e.g., Del. Code. Ann. § 109 (2016); see also Carol Goforth, Proxy Reform as a Means of Increasing Shareholder Participation in Corporate Governance: Too Little, But Not Too Late, 43 Am. U. L. Rev. 379, 405-07 (1994).

228. See Goforth, supra note 227, at 405-07.

229. See Frank Dobbin \& Jiwook Jung, Corporate Board Gender Diversity and Stock Performance: The Competence Gap or Institutional Investor Bias, 89 N.C. L. REv. 809, 820 (2011).

230. See id. at 820-21.

231. See Investments Overview, California State Teachers' Retirement System (2016), http://www.calstrs.com/investments-overview [https://perma.cc/FE3R-L2BR] ("CalSTRS is the nation's second largest public pension fund with assets totaling approximately $\$ 193.2$ billion as of September 30, 2016. The investment portfolio is broadly diversified into six asset categories.").

232. Global Governance Principles, California Public Employees' Retirement System (Mar. 16, 2015), https://www.calpers.ca.gov/page/investments/governance/corporate-engagements [https://perma.cc/E9E3-JM9S]. CalSTRs and CalPERs are concurrent retire- 
Taking a similar approach, TIAA-CREF adopted a Policy Statement on Corporate Governance encouraging nominating committees to "develop appropriate diversity criteria for director searches to ensure that candidates are drawn from the broadest possible pool of talent." ${ }^{33}$ In the Policy Statement, TIAA-CREF also signals its intent to support shareholder proposals that aim to require corporations to disclose board diversity practices. ${ }^{234}$ In the financial markets sector, UBS, an investment bank that frequently sponsors or underwrites equity securities in public offerings and private placements, has described diversity initiatives as an "economic imperative." 235

Other evidence supports the conclusion that institutional investors, equity sponsors, and early funders increasingly regard board diversity as an important investment criteria. ${ }^{236}$ Shareholders have formally and publicly introduced proposals to force the nominating and governance committees to incorporate language in their charters mandating consideration of diversity. Examples of recent shareholder proposals illustrate investors' frustration with the lack of board diversity. ${ }^{237}$ Over the last several years, California Public Employees' Retirement System (CalPERS), the largest public teachers' pension fund in the United States, submitted more than a handful of proposals encouraging nominating and governance committees to introduce board diversity initiatives. The campaigns have enjoyed

ment systems available to California public employees. The funds collaborate on a number of platforms including campaigns to enhance gender diversity initiatives before the nominating and governance committees of the companies whose equity shares they own. CalSTRS Continues to Advance Diversity on Corporate Boards, Calstrs (July 12, 2011), http://www.calstrs.com/news-release/calstrs-continues-advance-diversity-corporate-boards [https://perma.cc/G48A-GJ3T]. One gender diversity coalition sponsored twenty-five board proposals during the 2015 proxy season encouraging boards to adopt inclusive language in governance documents. Institutional Investors Working With Thirty Percent Coalition Continue to Push for Increased Gender Diversity in the Boardroom, ThIRTy PERCENT CoAlition (June 24, 2015), https://www.30percentcoalition.org/resources/coalition-arch ives/109-new-institutionla [https://perma.cc/D5P9-V6HK].

233. TIAA-CREF, TIAA-CREF Policy Statement on Corporate Governance 16 (6th Ed. 2011), https://www.tiaa.org/public/pdf/pubs/pdf/governance_policy.pdf [https:// perma.cc/V4QL-53PH].

234. Corporate Governance, Board Diversity, and Firm Value, supra note 13, at 34 (internal citations omitted) ("TIAA-CREF adopted a policy statement on corporate governance that states the board should be composed of 'qualified individuals who reflect diversity of experience, gender, race, and age.' Diversity is a key investment criterion for TIAA-CREF because they believe a diverse board will be less beholden to management. Additionally, the National Association of Corporate Directors Blue Ribbon Commission recommended that gender, racial, age, and nationality diversity should be considered in the selection of directors.") (citations omitted).

235. Nathaniel Parish Flannery, Corporate Diversity Initiatives: Risk and Reward for Investors, ForBEs (Dec. 2, 2011), http://www.forbes.com/sites/nathanielparishflannery/ 2011/12/02/corporate-diversity-initiatives-risk-and-reward-for-investors/\#20b6f869410f [https://perma.cc/BSX6-6X4J].

236. See, e.g., The Gender Advantage: Integrating Gender Diversity into Investment Decisions, Morgan Stanley, http://www.morganstanley.com/pub/content/dam/msdotcom/ ideas/gender-diversity-toolkit/Gender-Diversity-Investing-Primer .pdf?cid=2016ForbesBrandVoice [https://perma.cc/UWS9-PECN].

237. See, e.g., Adam Satariano, Apple Facing Criticism About Diversity Changes Bylaws, Bloomberg (Jan. 6, 2014), http://www.bloomberg.com/news/articles/2014-01-06/apple-facing-criticism-about-diversity-changes-bylaws [https://perma.cc/Q2HF-KZRX]. 
some success. After eight of the targeted companies in 2011 voluntarily adopted diversity policies, CalPERS withdrew their proposals. ${ }^{238}$

In 2014, responding to complaints from large and significant shareholders that Apple Inc.'s (Apple) eight member board of directors had only one woman, Apple added the following language to its board nominating and governance committee charter:

The nominating committee is committed to actively seeking out highly qualified women and individuals from minority groups to include in the pool from which board nominees are chosen. ${ }^{239}$

Investors, Trillium Asset Management LLC, and the Sustainability Group pressured Apple to acknowledge the lack of diversity on the corporation's board and expressed frustration that Andrea Jung, Former Chairman and Chief Executive Officer of Avon Products, Inc., ${ }^{240}$ was the only woman and the only racial minority on the company's board of directors at the time of their intervention. Only one month after amending the bylaws, an Apple press release signaled the retirement of board member Bill Campbell and appointment of Susan Wagner, founding partner and director of BlackRock. ${ }^{241}$ One year later, on October 1, 2015, Apple announced that James Bell, former chief financial officer and corporate president of The Boeing Company, would join Apple's Board of Directors. ${ }^{242}$ Bell is the second African-American to serve on the board.

Voluntarily and aggressively adopting and implementing diversity initiatives may be one of the best mechanisms of mitigating the risk of institutional investor or other activist inspired shareholder proposal campaigns. As increasing numbers of initiatives emerge each season, proactive development of useful standards that aim to incorporate inclusive language seems far less costly than the alternatives.

\section{B. Civil Rights Legislation}

An increasing number of federal regulatory obligations nudge corporations to consider the value of diversity on boards. Title VII of the Civil Rights Act of 1964 prohibits discrimination on the basis of race, color, sex, religion, or national origin. ${ }^{243}$ As a defense to a claim of a facially

238. CalSTRS Continues to Advance Diversity on Corporate Boards, CALSTRS (July 12 , 2011), http://www.calstrs.com/news-release/calstrs-continues-advance-diversity-corporate-boards [https://perma.cc/7NEH-PS3Y].

239. Jessica Guynn, Apple Pledges to Consider Adding More Women, Minorities to Board, L.A. Times (Jan. 6, 2014), http://articles.latimes.com/2014/jan/06/business/la-fi-tnapple-women-minorities-20140106 [https://perma.cc/9LPW-AC7M].

240. Andrea Jung is currently President and CEO of Grameen America. See Grameen AmERICA, Staff, http://www.grameenamerica.org/staff [https://perma.cc/E47V-P4RQ].

241. Press Release, Apple, Sue Wagner Joins Apple's Board of Directors (July 17, 2016), http://www.apple.com/pr/library/2014/07/17Sue-Wagner-Joins-Apple-s-Board-of-Directors.html [https://perma.cc/YHJ8-2S6R].

242. Press Release, Apple, James Bell Joins Apple's Board of Directors (Oct. 1, 2015), http://www.apple.com/pr/library/2015/10/01James-Bell-Joins-Apples-Board-of-Directors .html [https://perma.cc/9A7T-9EDN].

243. See 42 U.S.C. $\$ 2000$ e-2 (2012). The Age Discrimination in Employment Act and the Americans with Disabilities Act similarly prohibit discrimination on the basis of age 
neutral discriminatory practice under Title VII, the burden of proof shifts to the employer to demonstrate that the challenged practice is job related for the position in question and consistent with "business necessity." 244 Neither the statute nor the Equal Employment Opportunity Commission $(\text { EEOC })^{245}$ define the term "business necessity." Courts have employed various interpretations of this standard, generally adopting a standard that makes "business necessity" synonymous with an employment practice that is related to successful job performance; the standard is satisfied if the identified employment practice bears a "manifest relationship to the employment in question." 246 Courts have also applied the business necessity standard if performance of a job requires certain "important elements of work behavior" or the employment practice accurately ascertains one's ability to perform successfully the job in question. ${ }^{247}$ Courts have applied the standard where an employment practice is "necessary to safe and efficient job performance." 248

A solution to greater board diversity may involve use of antidiscrimination laws to reduce barriers to women's ascension to higher levels within the corporation. ${ }^{249}$ A number of high profile U.S. Supreme Court and

and disability, respectively. See Age Discrimination in Employment Act, 29 U.S.C. $\S 621-634$ (2012).

244. See 42 U.S.C. $\S 2000 \mathrm{e}-2(\mathrm{~K})(1)(\mathrm{A})(\mathrm{i})$.

245. Title VII authorizes the EEOC to enforce the Act. Initially, Title VII was interpreted only to authorize the EEOC to inform individuals that they had the right to file claims alleging that employers violated antidiscrimination laws and refer the cases to the Department of Justice for enforcement. See U.S. Equal Emp. Opportunity Comm'n, Pre 1965: Events Leading to the Creation of EEOC, http://www.eeoc.gov/eeoc/history/35th/pre1965/index.html [https://perma.cc/HBC2-MB9Q]. The continued widespread violations of Title VII prompted Congress to pass the Equal Employment Opportunity Act of 1972 which gave the EEOC authorization and jurisdiction to sue employers in matters where the EEOC found evidence of discriminatory practices. See id.

246. See James O. Pearson, Jr., What Constitutes "Business Necessity" Justifying Employment Practice Prima Facie Discriminatory Under Title VII of Civil Rights Act of 1964, 36 A.L.R. Fed. 9 (1978).

247. See Griggs v. Duke Power Co., 401 U.S. 424, 433 n.9 (1971); El v. Se. Pa. Transp. Auth., 479 F.3d 232, 242, 244 (3d Cir. 2007).

248. See El, 479 F.3d at 242.

249. See, e.g., Fairfax, supra note 99, at 602. In 1973, the Supreme Court decided McDonnell Douglass Corp. v. Green and held that once a showing of discrimination has been made, an employer may avoid liability by demonstrating a "legitimate, nondiscriminatory reason" for the employer's action. 411 U.S. 792, 802 (1973). McDonnell Douglass created the impression that courts would allow the articulation of any legitimate business purpose as a defense, rendering Title VII a toothless tiger. See id. In the $1970 \mathrm{~s}$, a number of decisions suggested that the Supreme Court intended to enable litigants to hold employers responsible for discriminatory employment practices. See, e.g., Espinoza v. Farah Mfg. Co., 414 U.S. 86, 95 (1973) (holding that Title VII protection extends to non-citizens); see also Alexander v. Gardner-Denver Co., 415 U.S. 36, 51 (1974) (holding that a union and employer cannot bargain away equal employment rights); see also Albemarle Paper Co. v. Moody, 422 U.S. 405, 419 (1975) (holding that backpay should be provided to employees who were discharged based on discriminatory reasons); see also The Pregnancy Discrimination Act of 1978, Pub. L. No. 95-555, 92 Stat. 2076 (prohibiting pregnancy-based discrimination); see also Hazelwood Sch. Dist. v. United States, 433 U.S. 299, 313 (1977) (holding the government could establish racial discrimination through statistic comparison of the racial composition of an employer's workforce against that of the relevant labor market, and that a disparity supports an inference of discriminatory practices); Trans World Airlines, Inc. v. Hardison, 432 U.S. 63, 75-76 (1977) (requiring employers to accommodate 
appellate court decisions have identified concerns that racial and gender stereotyping functions as an impediment to women's success. ${ }^{250}$

The Supreme Court has clearly determined that such gender stereotyping constitutes an impermissible form of discrimination when used in hiring and promotion decisions. ${ }^{251}$ There are, however, noteworthy limitations to federal antidiscrimination litigation. First, courts demonstrate clear deference to employers when asked to enforce protections against sex discrimination that relate to grooming standards. Second, there may be implicit biases that antidiscrimination litigation does not capture. Finally, the women who are the subject of discriminatory acts in hiring or promotion opportunities in the highest executive levels may value reputational or social capital in a manner that creates strong incentives to avoid antidiscrimination litigation. This Section surveys these concerns.

While discrimination on the basis of immutable characteristics inherent to protected classes under Title VII is actionable, a recent debate examining the application of this standard to businesses' formal grooming policies reveals new fault lines. Courts typically grant boards deference when they adopt internal governance policies. Employers may deem an employee's failure to comply with the employer's expectations or policies regarding appearance as a conduct or performance-related concern and consequently not hire, promote, or terminate the employee. Employers may defend their decisions by indicating that a reasonable and legitimate business purpose exists for the specific standard of professional appearance. ${ }^{252}$ The decision to adopt specific grooming policies, for example, have typically enjoyed protection from the ambit of federal antidiscrimination legislation.

The recent uptick in discrimination cases involving appearance standards, however, increasingly involve more aesthetic elements of beauty and style. ${ }^{253}$ In these murky waters, employees' protections and the em-

employees' religious needs so long as doing so would not create an undue hardship for employer).

250. Price Waterhouse v. Hopkins, 490 U.S. 228, 251 (1989) (explaining that in forbidding sex discrimination, "Congress intended to strike at the entire spectrum of disparate treatment of men and women resulting from sex stereotypes.").

251. Id.

252. See, e.g., D.C. Mun. Regs. tit. 4, §506.6 (2016) (providing that "[a]ny restriction or limitation on dress or appearance shall be a result of a reasonable business purpose. In the absence of a reasonable business purpose, an employer shall not refuse to allow an employee to wear a hair or dress style symbolic of natural origin, religion, or race.")

253. See EEOC v. Abercrombie \& Fitch Stores, Inc., 135 S. Ct. 2028, 2031 (2015) (involving a retail clothing store that refused to hire an employee who wore a hajib because her appearance did not confirm with their "Look Policy"). In the majority opinion joined by eight justices, the Supreme Court held that "an employer who acts with the motive of avoiding accommodation may violate Title VII even if he has no more than an unsubstantiated suspicion that accommodation would be needed." Id. at 2033. The Court further concluded that "[a]n employer may not make an applicant's religious practice, confirmed or otherwise, a factor in employment decisions. Id. at 2030. But see EEOC v. Red Robin Gourmet Burgers, Inc., No. C04-1291JLR, 2005 WL 2090677, *1 (W.D. Wash. Aug. 29, 2005) (involving a waiter with wrist tattoos and a restaurant chain's uniform and appear- 
ployers' obligations are far less clear. No federal or state statute expressly prohibits adverse employment decisions regarding weight-being too heavy or too thin. To overcome this concern, those alleging discrimination rely on the well-settled federal statutes and body of litigation that prevent age, gender, or race-based discrimination.

Indisputably, our society ascribes value to physical appearance. Attractive job candidates may benefit from the assumption that they are more intelligent, motivated, or capable. ${ }^{254}$ The appearance of a political candidate vying for the Presidency of the United States or the parent teacher association will get a bump in ratings if the electorate perceives her as more interesting to talk to or someone who is sexually more desirable..$^{255}$

ance policy required for tattoos to not be visible); Tinnin Law Firm, Can I Make Him 110 Take The Earring Off?, 12 No. 10 N.M. Emp. L. Letter 3 (October 2006); Joanne Deschenaux, Workplace Dress, Grooming Codes May Raise Legal Issues, Soc'y For Human Resource Mgmt. (Sept. 4, 2012), https://blog.shrm.org/public-policy/workplacedress-grooming-codes-may-raise-legal-issues [https://perma.cc/U2ZG-S55L]; Amanda B. Stubblefield, A Title VII Transition?: Protections for Transgender Persons in the Workplace, NAT'L L. Rev. (May 11, 2015), http://www.natlawreview.com/article/title-vii-transition-protections-transgender-persons-workplace [https://perma.cc/RP4A-53Z6].

254. See Steven McCord, Beauty in the Boardroom. . in the Eye of the Shareholder?, Odgers Berndtson (Mar. 25, 2014), http://www.odgersberndtson.com/en-fi/insights/ beauty-in-the-boardroom-in-the-eye-of-the-shareholder/ [https://perma.cc/BNB6-YNPY] ("Enbar Toledano, an academic at Emory University, argues that as early as infancy and throughout their lifetimes, physically attractive individuals are afforded more favourable treatment and enjoy better opportunities in virtually every aspect of life. 'Statistically, these individuals will receive more job offers, better advancement opportunities, and higher salaries than their less attractive peers,' she says."); Max Nisen, Check Out How Much More Often Beautiful Women Get Callbacks for Job Interviews, Bus. Insider (Sept. 9, 2013, 12:01 PM), http://www.businessinsider.com/beautiful-people-get-more-job-interviews-2013-9 [https://perma.cc/C5TD-3XCW] ("Life really is easier for attractive people. They make more money, get promoted faster, and many times are simply more successful. And according to a new study, they have a much easier time job hunting. ... [Studies have shown that] attractive people had a [ ] higher callback rate than unattractive ones, with no variation in qualification."); Laura Sinberg, Think Looks Don't Matter? Think Again, Forbes (Dec. 5, 2009, 10:00 AM), http://www.forbes.com/2009/12/05/appearance-workpay-forbes-woman-leadership-body-weight.html [https://perma.cc/E4KG-7JWB] ("Your looks can help-or hinder-your chances of getting a well-deserved promotion, regardless of qualifications, especially in a sour economy when advancements are few and hard to come by. Women who advance most at work, studies agree, are more attractive, thinner, taller and have a more youthful appearance than their female colleagues who are promoted less often.").

255. Jess Cartner-Morley, Hillary Clinton's Wardrobe Matters-But Not From a Fashion Perspective, The Guardian, (June 8, 2016, 12:47 PM), https://www.theguardian.com/ us-news/shortcuts/2016/jun/08/hillary-clinton-wardrobe-matters-but-not-fashion-perspective [https://perma.cc/5WRY-NVSF]. For instance, Cartner-Morley stated:

In the era of personality politics, critiquing a politician's wardrobe is just another way of asking: who would you rather have a pint with? When we discuss what politicians wear, we are talking about the same fundamental issues - what are they really like, what would they be like to hang out withas when we debate which leader we'd go to the pub with.... What is illogical is the way in which we hold women to a higher standard of style than we do men. Looking presentable and appropriate will pass muster for a man, but we expect more of women. To paraphrase Ginger Rogers, women in politics have to do what the men do, but backwards in high heels and while wearing on-trend yet age-appropriate clothes, patriotically flying the flag for their country's top design talent and without spending extravagantly. We want them to have the Michelle Obama knack of dressing in a way that is simulta- 
Some studies have shown that "beauty in the boardroom" is associated with increased stock prices. 256 According to one recent study, "attractive CEOs boost stock performance when they appear on television, receive higher total compensation, and achieve better returns on their first days on the job." 257 The study also found that companies that had CEOs perceived by a random sample of people to be "more competent, dominant and mature," tended to be more profitable than companies without such CEOs. ${ }^{258}$ The opinions in the surveyed group related solely to the CEO's facial appearance and did not involve any evaluation of the executives' expertise or job performance. ${ }^{259}$

A cursory glance at the most recent wave of employment discrimination litigation reveals an increasing number of suits inquiring about the application of grooming standards. Is it acceptable for employers to prefer employees based on physical appearance, meaning the use of makeup, body art (tattoos or jewelry), style of dress, weight, hairstyle, length of hair, or facial hair? Courts' responses to plaintiffs' suits alleging discrimination based on grooming are as varied as the panoply of personal styles that inspire the litigation in this area.

There are legitimate business interests in employee appearance in many contexts. An employer may demand a uniform dress code or personal grooming modifications where such obligations are motivated by an intent to comply with express state or federal laws. For example, persons working in a kitchen may be required to wear hairnets. It would be difficult to deny an employer the right to demand stringent guidelines in cases where an employee's job performance exposes the employee or customers to environmental or other hazards.

The reach of Title VII litigation increasingly threatens to reach the boardroom. While Title VII prohibits intentional discrimination in employment decisions, claims under Title VII must demonstrate that an employer's actions are consciously motivated by animus, ${ }^{260}$ stereotypes, ${ }^{261}$ and consideration of a protected classification ${ }^{262}$-as well as uninten-

neously formidable and warm. The likability problem is real for Clinton, and

Id. clothes are part of it.

256. McCord, supra note 254 (“A 2010 report by academics at Duke University found that CEOs are more likely than non-CEOs to be rated as competent based on their physical appearance, and that executive compensation is linked to this perception. ... In similar vein, a study by psychologists at Tufts University found that companies tend to be more profitable if they have a CEO with a face rated by a random sample of observers as being more competent, dominant and mature.").

257. Id. (citing Joseph T. Halford \& Hung-Chia Hsu, Beauty is Wealth: CEO Appearance and Shareholder Value, (Dec. 19, 2014), http://papers.ssrn.com/sol3/papers.cfm?abs tract_id=2357756).

258. Id.

259. Id.

260. See McDonnell Douglas Corp. v. Green, 411 U.S. 792, 801 (1973); see also Staub v. Proctor Hosp., 562 U.S. 411, 413 (2011).

261. Price Waterhouse v. Hopkins, 490 U.S. 228, 294 (1989).

262. Ricci v. DeStefano, 557 U.S. 557, 592-93 (2009) (holding that municipal government's consideration of race in its decision not to certify promotional exam results, which 
tional discrimination. ${ }^{263}$ As the breadth of litigation under Title VII expands, there is pressure to explain why diverse rank-and-file hires are not elevated to management or senior management. One can imagine litigation alleging discrimination that violates Title VII in the context of promotion to senior management or nomination to a board based on evidence that a candidate was improperly denied promotion or nomination on the basis of sex discrimination. Early evidence suggests that such claims are unlikely to overcome the protections afforded to employers' cries for deference and autonomy in evaluating beauty or appearance. ${ }^{264}$

Courts, captivated with descriptions of claims expressly related to race, have failed to appreciate the link between these cases and cases that describe grooming standards that involve closely interwoven race or gender based characteristics. ${ }^{265}$ What greater concerns, however, might we have about the probability that such subjective grooming standards might impact search firms' review of board candidate profiles as they prepare to brief a nominating and governance committee of a large Fortune 500 company?

The inner chambers of corporate executive and board searches are opaque and shrouded in mystery. The determination that a candidate "qualifies" for consideration is extremely subjective. Having overcome initial inquiries regarding qualifications, senior executive and board candidates must also satisfy unspoken codes that evaluate whether they possess the "intangible" characteristics that satisfy search committees, nominating, and governance committees, and ultimately, investors.

As described in Part II, in the context of financial markets, homogeneity is concerning because it may incite overconfidence or fuel the structural, relational, and confirmation biases. In many industries, the effects of grooming policies that have a disparate impact on gender and racial diversity may be quite harmful to the minority and women job candidates. In financial markets, the lack of diversity may engender more endemic concerns.

disproportionately impacted African American firefighters and thus resulted in a negative employment decision for white male firefighters and a Hispanic male firefighter, constitutes intentional race discrimination under Title VII).

263. Griggs v. Duke Power Co., 401 U.S. 424, 431 (1971) (adopting a disparate impact theory of discrimination in Title VII cases to redress "not only overt discrimination but also practices that are fair in form, but discriminatory in operation"). To clarify the application of Title VII, Congress modified the statute in 1991 to require a plaintiff to establish that: 1) a facially neutral employment practice causes a disproportionate impact on individuals who share the same religion, color, national origin, race, or sex; and 2) the covered employer fails to adopt a less discriminatory alternative that is job related and meets the employer's business needs. 42 U.S.C. $\$ 2000 \mathrm{e}-2(\mathrm{k})(1)(\mathrm{A})-(\mathrm{C})(2000)$.

264. See EEOC v. Catastrophe Mgmt. Sols., 837 F.3d 1156 (11th Cir. 2016). But see EEOC v. Catastrophone Mgmt. Sols., No. 14-13482, 2016 WL 7210059 (holding that the "EEOC's original and proposed amended complaint did not state a plausible claim that [the defendant employer] intentionally discriminated against [an employment applicant] because of her race" when the defendant employer requested that the employment applicant cut her dreadlocks hair style).

265. Id. at 1172; Rogers, 527 F.Supp., at 234. 
Second, hiring and promotion decisions pose a unique set of concerns because candidates are vulnerable to implicit stereotypes or biases that are not articulated. ${ }^{266}$ The employer may be unaware of the influence of the stereotype on her decision-making process. ${ }^{267}$ Women may be reluctant to bring claims or reticent to destroy social capital developed over years of working with an employer. ${ }^{268}$ Women reaching for employment in the highest echelons may be concerned about negative reactions or reputation effects of their complaints regarding sex discrimination. ${ }^{269}$ As a result, antidiscrimination claims may not enable employees of a company to hire and promote women, leaving a clogged or lagging pipeline. 270

\section{As Darren Rosenblum explains,}

U.S. equality jurisprudence's emphasis on antidiscrimination law and theory reflects the primacy of the private sector. The context of a privatized world forces gender justice efforts to play defense. Antidiscrimination work seeks to punish and prevent discriminatory conduct, rather than shift underlying inequities in favor of broader balance. These efforts fail to rectify gender-based power disparities ${ }^{271}$

While the private sector continues to struggle with these questions, military grooming guidelines have acknowledged the disparate impact that hair style or grooming bans may have on protected communities. Military grooming codes, known for a strict adherence to uniformity began in recent years to adopt a more inclusive approach. Uniformity as a core value of military grooming policies creates a justifiable rational for limiting departures from standards. The effect of the more progressive military

266. See Rachel D. Godsil et al., Science of Equality, Volume 2: The Effects of Gender Roles, Implicit Bias and Stereotype Threat on the Lives of Women and Girls 31, Perception Institute (Oct. 2016), https://perception.org/wp-content/uploads/ 2016/10/Science-of-Equality-Vol-2.pdf [https://perma.cc/A65B-B96Y]. Recent studies provide valuable insight into the significance of implicit bias, which can be understood as "a bias we aren't aware of having. Our minds process the enormous amount of stimuli we encounter every day with great efficiency. We unconsciously sort things into 'schema,' or categories ... which allows us to respond accordingly with limited conscious attention or thought." Id. (citation omitted). Explaining how implicit biases operate clarifies why these attitudes create concerns in the context of promotion and hiring decisions. See id. at 33. The authors of the Perception Institute study on the Science of Equality explain that implicit biases or the "instant processes of categorization and attitude association apply to the people we encounter ... guiding our social interactions. Such automatic organization of the stimuli we encounter, while efficient, is not without its potential for bias. In some instances, associations are neutral (e.g., 'one who teaches' and 'adult' are neutral attributes associated with the category of 'teacher'), but many social categories are widely associated with attributes that aren't necessarily neutral and are, in fact, limiting. For instance, the social category of 'woman' is typically associated with the attributes 'emotional,' 'submissive,' and 'dependent." "Id. at 32.

267. Id.

268. See Lisa M. Fairfax, supra note 99, at 603.

269. Rachel D. Godsil et al., supra note 266, at 39.

270. Lisa M. Fairfax, supra note 99, at 603.

271. Darren Rosenblum, Feminizing Capital: A Corporate Imperative, 6 Berkeley Bus. L.J. 55, 58 (2009). 
grooming standards illustrates the potential for embracing a more diverse candidate pool in corporate service. The military groom standards prompt one to conclude that choosing a more inclusive path is not a slippery slope toward loss of professionalism. ${ }^{272}$

\section{Derivative Litigation: A Risk Management Case Study}

In the years leading to the recent financial crisis, the residential lending unit of Citigroup, Inc. (Citigroup), a large, storied financial institution, aggressively engaged in originating and warehousing residential mortgages. ${ }^{273}$ Citigroup was well compensated for acting as a mortgage originator and, through a process in which it repackaged debt products, Citigroup earned significant fees for creating collateralized debt products (CDO). ${ }^{274}$ By 2007, Citigroup had garnered a sizeable role in the CDO market. ${ }^{275}$ When the market for residential mortgages began to decline, a wave of losses engulfed Citigroup's balance sheet. ${ }^{276}$ The losses in the residential mortgage market and the CDO market thrust Citigroup and other large financial institutions that held similar portfolios of assets toward insolvency. ${ }^{277}$

Responding to the plummeting stock price, Citigroup shareholders initiated a derivative suit alleging that directors breached their fiduciary duties by failing to diligently monitor and manage the business's risks related to the subprime mortgage market. ${ }^{278}$ Shareholders argued that Citigroup elected to increase its exposure in the subprime mortgage market long after other firms began to retreat. ${ }^{279}$ Moreover, shareholders posited that there were well-known and widely adopted risk management strategies that would have enabled the firm to mitigate its exposure to losses in the event of a sharp decline in the price of subprime mortgages. ${ }^{280}$ Directors, shareholders argued, ignored "red flags" that warned of widespread defaults in the subprime mortgage market. ${ }^{281}$

Derivative litigation involves a claim by a shareholder on behalf of the corporation alleging that a director breached a fiduciary duty owed to the corporation. Over the last several decades, procedural hurdles and courts' narrow depiction of directors' fiduciary duties have rendered shareholder derivative claims almost meaningless. ${ }^{282}$

272. See generally Kristin Johnson, Resolving the Title VII Partner-Employee Debate, 101 Mich. L. Rev. 1067 (2003).

273. In re Citigroup Inc. S'holder Derivative Litig., 964 A.2d 106, 113 (Del. Ch. 2009).

274. Id.

275. Id.

276. Id. at $13-114$

277. Id. at $114-115$.

278. Id.

279. Id. at 115 .

280. Id. at 114 .

281. Id. at 115 .

282. Delaware law offers the preeminent jurisprudence on shareholder derivative claims. Delaware dominates the charter market; consequently, the vast majority of publicly traded companies are incorporated in the state of Delaware. Under Delaware law, shareholders must first make demand on the board of directors prior to initiating a civil suit 
The Delaware court's description of directors' fiduciary duties in In re Caremark, an opinion intended to simply approve a settlement, introduced a framework that significantly limited shareholders' ability to use derivative claims to hold directors accountable for board decisions. ${ }^{283} \mathrm{In}$ In re Caremark, the court explained that plaintiffs may assert two different types of claims alleging that directors violated their fiduciary duty to monitor the affairs of the business. ${ }^{284}$ The first class of claims involve allegations that directors made grossly negligent decisions. Delaware courts have plainly and frequently reinforced their reticence to engage in hindsight evaluations of boards' decision.285 According to Delaware courts, judges are ill-equipped to evaluate the substance of business decisions. ${ }^{286}$

When evaluating board decisions, Delaware courts have long employed a doctrine known as the business judgment rule-a deferential standard that presumes that directors' decisions are informed, rational, and made in good faith. ${ }^{287}$ The business judgment rule avoids judicial second-guessing or hindsight bias that may occur if judges engage in after-the-fact evaluations of the substance or content of directors' decisions. The business judgment rule protects directors' decisions in the first group of claims as long as directors employ a rational process in which all material information is given reasonable consideration. ${ }^{288}$ As a result, the business judgment rule limits evaluation of directors' decisions to an examination of the board's process. ${ }^{289}$

Following Caremark, Stone v. Ritter clarified that for the second class of Caremark claims, plaintiffs would have to establish that directors acted in bad faith by failing to establish a compliance and reporting system or by failing to monitor an existing compliance system. ${ }^{290}$ Plaintiffs may demonstrate that directors acted in bad faith by offering evidence that directors (a) utterly failed to assure that a reasonable reporting or information system or controls existed, or (b) having created such systems, the directors consciously failed to monitor or oversee the operation of the

\footnotetext{
unless there is evidence that demand would be futile. See Mark S. Roe, Delaware's Shrinking Half-Life, 62 Stan. L. Rev. 125, 133-35 (2009).

283. See generally In re Caremark Int'l Inc. Derivative Litig., 698 A.2d 959 (Del. Ch. 1996).

284. Id. at 967.

285. Id.

286. Id.

287. Id. at 967.

288. Id.

289. Id.

290. Stone v. Ritter, 911 A.2d 362, 370 (Del. 2006). For a careful exploration of the meeting of the term "good faith" in shareholder derivative litigation involving directors' obligations to monitor a firm's compliance with positive legal obligations, see In re Walt Disney \& Co. Derivative Litigation, 907 A.2d 693, 753 (Del. Ch. 2005). Proving bad faith requires demonstrating that the directors' "insolence was so persistent that it could not be ascribed to anything other than a knowing decision not to even try to make sure the corporation's officers had developed and were implementing a prudent approach to ensuring law compliance." In re Citigroup, Inc. v. S'holder Derivative Litig., 964 A.2d 106, n. 47 (Del. Ch. 2009).
} 
program. ${ }^{291}$ By failing to oversee the system or controls, directors limited their ability to remain informed regarding the risks or problems that most require their attention. ${ }^{292}$

While the claims in Citigroup did not refer to the board's lack of diversity as contributing to the decision to remain aggressive in the subprime mortgage market, one of the studies in Part II explains that boards of mortgage originating financial institutions that had one or more women during the crisis made better decisions regarding credit policies or evaluating credit lending criteria or simply mitigated risk exposure by electing not to invest heavily in the subprime mortgage market. Presenting evidence that other firms avoided or mitigated the risk exposure that almost leveled Citigroup likely buttressed shareholder claims regarding directors' failure to manage financial, market, and credit risks related to the subprime mortgage market and the securitization industry.

One of the most important claims for the discussion of board diversity raised in the Citigroup litigation relates to Citigroup's decision to maintain an aggressive position in the mortgage and CDO market. While the Citigroup court explained that directors did not breach their fiduciary duty to monitor risk, ${ }^{293}$ the litigation raises important questions about the board decision-making process and dynamics that led the board to conclude that it was advisable to continue to penetrate the residential mortgage and CDO market.

The after-the-crisis evaluation of the bankruptcy of Lehman Brothers and the insolvency or near failure of other financial institutions shows that there is clear evidence that financial institution boards may benefit from carefully developed risk management tools. ${ }^{294}$ Greater inclusion at the senior executive and board levels of management may well offer such a tool. As the social psychology discussion above explains, many factors influence the dynamics of group decision-making. For many years, scholars, empiricists, and regulators will be focused on identifying factors that influence a board's ability to engage in effective risk assessment. The social psychology literature and empirical evidence suggests that gender diversity policies present one of the most underemployed risk mitigation tools.

In addition, evidence in Part II expressly demonstrates by empirical evidence that the greater participation of women in the C-suite and on the boards of financial institutions may enhance the use of known and widely adopted risk management tools such as maintaining higher levels of capital on reserve. Other studies drawing on social psychology in Part II suggest that women are likely to introduce contrarian perspectives in their service. While extensive disagreement may be disruptive, the studies

291. Stone, 911 A.2d at 370.

292. Id.

293. In re Citigroup Inc. S'holder Derivative Litig., 964 A.2d 106, 123-126 (Del. Ch. 2009).

294. See Johnson, supra note 165 , at 888 . 
discussed in Part II demonstrate that an optimal level of contrarian participation in board decisions ensures a robust and comprehensive discussion of important questions.

\section{CONCLUSION}

This Article explores the limited but valuable behavioral economics and empirical evidence examining the relationship between gender diversity and risk management decision-making. Based on empirical data that establishes the value of gender diversity in decision-making, this Article proposes that financial services institutions may mitigate risk by embracing greater gender diversity in their leadership ranks. Studies reveal that heterogeneous groups may have greater success overcoming herd behavior, groupthink, and relational biases that impact senior executives and boards of directors' risk management decisions.

Based on the survey of empirical evidence that suggests that gender diversity positively impacts group dynamics and improves risk management outcomes, this Article concludes that businesses, scholars, and researchers ought to devote resources to effectively explore the relationship between gender diversity and risk management decisions A more robust and creative market for solutions will create opportunities for women to advance in leadership roles within financial institutions and enhance firms' ability to comply with risk oversight objectives. 